Article

\title{
TerraSAR-X Time Series Fill a Gap in Spaceborne Snowmelt Monitoring of Small Arctic Catchments-A Case Study on Qikiqtaruk (Herschel Island), Canada
}

\author{
Samuel Stettner ${ }^{1, *(\mathbb{D})}$, Hugues Lantuit ${ }^{1,2}{ }^{,}$Birgit Heim ${ }^{1}(\mathbb{D})$, Jayson Eppler ${ }^{3}$, Achim Roth ${ }^{4}$, \\ Annett Bartsch ${ }^{5}$ and Bernhard Rabus ${ }^{3}$ \\ 1 Alfred Wegener Institute, Helmholtz Centre for Polar and Marine Research, Telegrafenberg A45, \\ 14473 Potsdam, Germany; hugues.lantuit@awi.de (H.L.); birgit.heim@awi.de (B.H.) \\ 2 Institute of Earth and Environmental Science, University of Potsdam, Karl-Liebknecht-Str., 24-25, \\ 14476 Potsdam-Golm, Germany \\ 3 Synthetic Aperture Radar Laboratory, Simon Fraser University, 8888 University Dr. Burnaby, \\ BC V5A 1S6, Canada; jayson_eppler@sfu.ca (J.E.), bernhard_t_rabus@sfu.ca (B.R.) \\ 4 Department Land Surfaces, German Aerospace Center Oberpfaffenhofen, 82234 Weßling, Germany; \\ achim.roth@dlr.de \\ 5 b.geos, Industriestrasse 1, 2100 Korneuburg, Austria; annett.bartsch@bgeos.com \\ * Correspondence: samuel.stettner@awi.de; Tel.: +49-331-288-20114
}

Received: 4 June 2018; Accepted: 20 July 2018; Published: 21 July 2018

\begin{abstract}
The timing of snowmelt is an important turning point in the seasonal cycle of small Arctic catchments. The TerraSAR-X (TSX) satellite mission is a synthetic aperture radar system (SAR) with high potential to measure the high spatiotemporal variability of snow cover extent (SCE) and fractional snow cover (FSC) on the small catchment scale. We investigate the performance of multi-polarized and multi-pass TSX X-Band SAR data in monitoring SCE and FSC in small Arctic tundra catchments of Qikiqtaruk (Herschel Island) off the Yukon Coast in the Western Canadian Arctic. We applied a threshold based segmentation on ratio images between TSX images with wet snow and a dry snow reference, and tested the performance of two different thresholds. We quantitatively compared TSX- and Landsat 8-derived SCE maps using confusion matrices and analyzed the spatiotemporal dynamics of snowmelt from 2015 to 2017 using TSX, Landsat 8 and in situ time lapse data. Our data showed that the quality of SCE maps from TSX X-Band data is strongly influenced by polarization and to a lesser degree by incidence angle. VH polarized TSX data performed best in deriving SCE when compared to Landsat 8. TSX derived SCE maps from $\mathrm{VH}$ polarization detected late lying snow patches that were not detected by Landsat 8 . Results of a local assessment of TSX FSC against the in situ data showed that TSX FSC accurately captured the temporal dynamics of different snow melt regimes that were related to topographic characteristics of the studied catchments. Both in situ and TSX FSC showed a longer snowmelt period in a catchment with higher contributions of steep valleys and a shorter snowmelt period in a catchment with higher contributions of upland terrain. Landsat 8 had fundamental data gaps during the snowmelt period in all 3 years due to cloud cover. The results also revealed that by choosing a positive threshold of $1 \mathrm{~dB}$, detection of ice layers due to diurnal temperature variations resulted in a more accurate estimation of snow cover than a negative threshold that detects wet snow alone. We find that TSX X-Band data in $\mathrm{VH}$ polarization performs at a comparable quality to Landsat 8 in deriving SCE maps when a positive threshold is used. We conclude that TSX data polarization can be used to accurately monitor snowmelt events at high temporal and spatial resolution, overcoming limitations of Landsat 8 , which due to cloud related data gaps generally only indicated the onset and end of snowmelt.
\end{abstract}


Keywords: Snow Cover Extent (SCE); TerraSAR-X; Landsat; wet snow; small Arctic catchments; satellite time series

\section{Introduction}

The evolution of snowmelt is a crucial component in the seasonal cycle of Arctic ecosystems; affecting temporal and spatial patterns of hydrology, vegetation, and biogeochemical processes. Snow also influences the ground thermal regime by insulating permafrost-affected soils from cold temperatures in winter and from warm temperatures in spring [1-3]. Deeper and prolonged winter snow cover can increase permafrost temperatures and over time can lead to increased active layer thickness, soil nutrient availability, and shifts in vegetation composition [4-7]. Late lying snow patches affect the soil moisture content and thermal properties of the active layer late in the season and create unique vegetation communities beneath and in their vicinity [8]. Both prolonged winter snow and late lying snow patch dynamics directly affect heterotrophic soil respiration and consequently carbon cycling [6,9-13].

The time between the onset and end of snowmelt initiates the hydrological year, drives vegetation phenology, and marks an increase in soil biogeochemical activity [14-16]. In small Arctic catchments, snowmelt is often the most important hydrological driver and generates the majority of annual discharge [17]. The timing of snowmelt, as opposed to temperature, also drives the onset of vegetation phenology and influences subsequent phenological phases and overall fitness of individual plants $[18,19]$. On a regional scale, spring snow cover in May and June in the Northern Hemisphere has decreased drastically in the last 30 years following trends of increasing air temperatures and reductions in sea ice extent and duration [20]. On a local scale, changes in winter precipitation in the Arctic are expected to be highly variable in space and time [21]. The spatial variability of snow cover extent (SCE) and the temporal variability of snowmelt, expressed on a catchment scale through changes in fractional snow cover (FSC), is inherently high due to low vegetation and snow redistribution by strong and prevailing wind patterns [22,23]. Adding to the uncertainty in changes to SCE and snowmelt is the observed expansion of tall shrubs across the Arctic, which will greatly impact the distribution and depth of snow [24,25]. Consequently, the monitoring of snowmelt at high spatial $(30 \mathrm{~m})$ and temporal scales (daily) is important to better understand the impacts of changing SCE on the abiotic and biotic functioning of small catchments in a rapidly changing Arctic. In situ knowledge about snow properties such as snow depth, snow density and the snow water equivalent at the time of image acquisition, are important parameters when undertaking snow related microwave satellite studies [26]. However, the snowmelt period is a logistically challenging time in Arctic regions to conduct in situ work because of unstable sea and river ice conditions as well as very wet ground surfaces due to snowmelt and permafrost thaw.

Currently, in Arctic regions there is no operational product available that captures snow cover in simultaneously high temporal and spatial resolution. Snow cover products from remote sensing data sources are predominantly derived from optical and microwave sensors. To detect snow, optical sensors rely on the high proportion of reflected radiation in the visible spectrum in contrast to the very low reflection in the near infrared part of the electromagnetic spectrum. Common optical sensors for snow cover retrieval include the Moderate Resolution Imaging Spectroradiometer (MODIS), the Advanced Very High Resolution Radiometer (AVHRR), and the Landsat series [27]. MODIS has a spatial resolution of up to $250 \mathrm{~m}$ and theoretically delivers a daily snow product. AVHRR also delivers daily snow cover information with a $1 \mathrm{~km}$ spatial resolution. Landsat 8 acquires imagery at a spatial resolution of $30 \mathrm{~m}$ and with a revisit time of 16 days [28]. The theoretical temporal resolution of MODIS and AVHRR would be sufficient to track the temporal dynamic of snowmelt, but their spatial resolution is not sufficient to capture snowmelt at the small Arctic catchment scale. Landsat 8 offers a spatial resolution sufficient for analysis at the small catchment scale and in Arctic regions converging satellite 
orbit paths increase the temporal resolution, which would allow monitoring of the highly dynamic phenomenon of snowmelt [29]. However, the retrieval of snow cover from optical sensors in Arctic regions is often challenging due to complete and fragmented cloud cover which introduces gaps in the time series or errors in snow detection [30]. This limits optical time series spatially and temporally, consequently prohibiting fine-scale mapping of the rapid and spatially variable phenomenon of snowmelt. Microwave satellite systems operate largely unaffected by atmospheric distortions from water vapor and clouds and also are independent of solar illumination; as a result they can acquire data at all times. Passive microwave systems can detect snow cover and snow properties at high temporal resolution [31], but the acquired imagery is at a coarse $\mathrm{km}$ scale spatial resolution, which is unsuitable for small catchment analyses. Recent active microwave satellite missions operating in Synthetic Aperture Radar (SAR) modes can obtain imagery in sufficient spatial and temporal resolution for small catchment based analysis.

The German active microwave TerraSAR-X (TSX) satellite mission has high potential to address the temporal limitations of operational optical and spatial limitations of other microwave missions by reliably providing imagery in high spatial and reasonable temporal resolution through combining different orbits and viewing geometries. The TSX satellites operate at a polar sun-synchronous orbit with an orbital revisit time of 11 days during which they revisit the same orbital location two times with the same viewing geometry. Satellite missions with polar orbits in general have a higher density of orbits and resulting coverage in Arctic regions because the flight paths converge from the equator to the poles. A fixed antenna beam is used to acquire imagery in the StripMap imaging mode of TSX at a spatial ground range resolution of 1.7 to $3.5 \mathrm{~m}$ with incidence angles between $20^{\circ}$ and $45^{\circ}$. In the StripMap mode the swath has the dimensions of $30 \mathrm{~km}$ and up to $1500 \mathrm{~km}$ in cross track and along-track, respectively [32]. TSX is a SAR system that emits pulses in the microwave length of the electromagnetic spectrum, which propagate through the atmosphere. The SAR antenna receives the pulse echoes after being scattered by objects on the Earth's surface, transmitting the physical structure and dielectric properties of the surface. The amplitude of these echoes determines the backscatter intensity and can be used to describe and classify different surfaces. However, a prominent feature of SAR imagery is the speckle effect which introduces a variation to the image texture in a granular pattern that does not arise from the imaged surface but from the SAR system itself. This signal is often regarded as unwanted noise and makes averaging necessary to retrieve the actual mean backscatter amplitude of the surface.

Air, ice and at times liquid water make up a snowpack. The main parameters differentiating the backscatter of dry snow and soil background is the mass of snow or snow water equivalent (SWE), the size of the snow grains, and the roughness and dielectric properties of the soil [33,34]. As air does not influence the transmitted microwave signal [35,36], the propagation and backscatter of microwaves from a snowpack depend on the dielectric constants of ice and water, which are very different and can be used to map snow volume and cover [37,38]. In general, wet snow is easily classified due to free water within the snowpack strongly attenuating the microwave signal $[39,40]$. The ability of X-band SAR systems like TSX or COSMO-SkyMed to map wet snow due to attenuation of the microwave signal by free water within the snowpack, has been widely reported $[38,40-43]$. The presence of wet snow in a snowpack is indicative of the onset of snowmelt and, therefore, offers an opportunity to monitor snowmelt dynamics in high spatial and temporal detail.

In addition to wet snow detection, re-freezing of snow layers can be detected using SAR data. Previous research has shown that the formation of ice crusts is highly visible in Ku-Band data [44-46]. A metamorphism of snow crystals due to compaction, sintering and temperature change, in turn influences the dielectric properties of the snowpack. During the snowmelt period, diurnal changes in temperature from below to above freezing can result in the formation of ice layers and can greatly influence backscatter signals [47]. The detection of both wet snow and ice crusts by SAR data expands the utility of this approach in monitoring snow melt dynamics in the Arctic which are strongly affected by diurnal temperature changes and, therefore, ice layer formation. 
Our research goal is to resolve the spatiotemporal patterns of the highly dynamic seasonal snowmelt in small Arctic catchments by combining time-series of multi-orbit and multi-polarization TSX data with optical remote sensing data and in situ observations. We investigate snowmelt dynamics of 3 years in small Arctic catchments at the long-term Canadian Arctic terrestrial observatory Qikiqtaruk (Herschel Island) that is also part of the World Meteorological Organization's Polar Space Task Group initiated TSX long-term monitoring dedicated to permafrost applications [48]. We address the following research questions: (1) How does TSX perform in mapping SCE in small Arctic tundra catchments compared to Landsat 8 optical satellite data; (2) How does TSX resolve temporal dynamics of snowmelt compared to in situ observations, and (3) What are the spatiotemporal dynamics of fractional snow cover from 2015 to 2017 in the small catchments of Qikiqtaruk? In order to answer these questions, we performed a quantitative comparison of snow cover extent (SCE) from Landsat 8 with SCE products derived from three different TSX polarizations at different incidence angles. In a second step, we validate catchment based FSC derived from TSX and Landsat 8 with in situ observations and relate the results to catchment characteristics.

\section{Study Area}

Qikiqtaruk (Herschel Island; $69^{\circ} 34^{\prime} \mathrm{N} ; 138^{\circ} 55^{\prime} \mathrm{W}$ ) is located off the northwestern Yukon coast in the Western Canadian Arctic, approximately $2 \mathrm{~km}$ from the mainland (Figure 1). The climate of Qikiqtaruk is polar continental with mean annual air temperatures between $-9.9^{\circ} \mathrm{C}$ and $-11^{\circ} \mathrm{C}$ and mean annual precipitation between 161 and $254 \mathrm{~mm}$ year ${ }^{-1}$ [49]. The dominant wind direction is northwest and storms are frequently observed in late August and September [50]. The island is characterized by rolling hills with a maximum elevation of $183 \mathrm{~m}$ above sea level and a polygonal tundra that is dissected by a variety of different valley types [51,52]. There is only one larger water body in the center of the Island, referred to by the local community as Water lake.

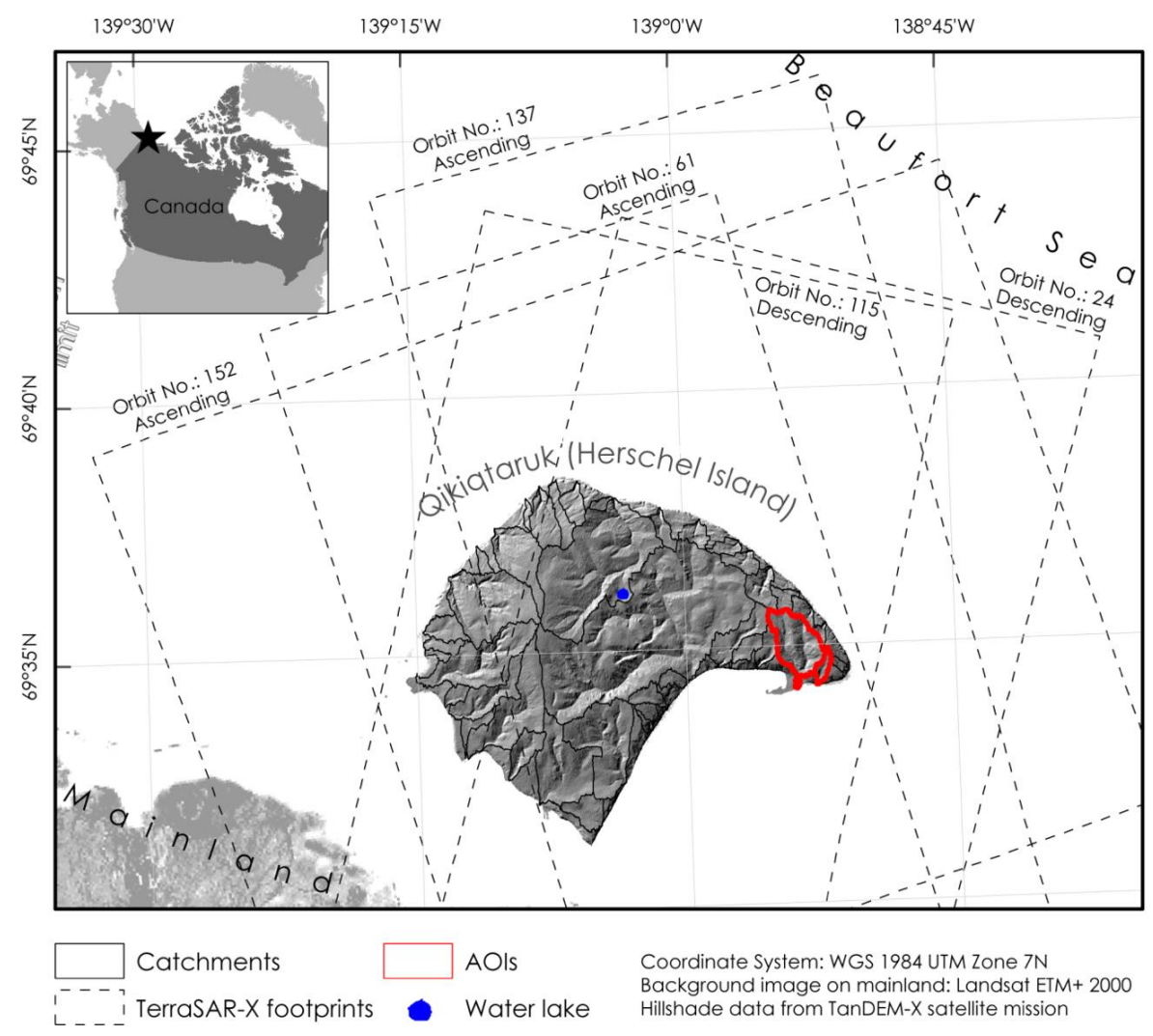

Figure 1. Location of Qikiqtaruk in the southwestern Beaufort Sea Region and footprints of TerraSAR-X imagery. 
The vegetation on Herschel Island belongs to the lowland tundra and can be assigned to subzone E of the circumarctic vegetation map (CAVM) [53] or the Low Arctic, respectively [54-56]. The lowland tundra vegetation type makes up the majority of the Arctic tundra. The vegetation is dominated by graminoids and dwarf shrubs, with a relatively species-rich forb flora and a well-developed moss layer [55-57]. The sediments are unconsolidated and mostly fine-grained glacigenic material with marine origin [58,59]. The thickness of the active layer generally ranges between $40 \mathrm{~cm}$ and $60 \mathrm{~cm}$ in summer, depending on topography $[60,61]$. Permafrost on Qikiqtaruk is continuous and can be extremely ice-rich with mean ice volumes ranging between 30 and $60 \mathrm{vol} \%$, and up to values $>90 \mathrm{vol} \%$, when underlain by massive ground ice beds [62-64]. While mean annual air temperatures have been stable in the Western Canadian Arctic between 1926 and 1970, a total increase of $2.7^{\circ} \mathrm{C}$ was observed here between 1970 and 2005 [60]. The effect of this increase of temperature is also exhibited on Qikiqtaruk Island where a deepening of the active layer by 15 to $25 \mathrm{~cm}$ has been documented between 1985 and 2005 [60].

Seasonal snow cover typically starts to develop in September and lasts until June. Most snow falls in autumn before sea ice forms and when the ocean still provides a source of liquid water [60]. During winter, strong winds from northwest or northeastern directions affect the snow distribution. Because the tundra vegetation on elevated areas is sparse and trapping capacities are low, the strong winds blow much of the upland surfaces clear of snow and consequently large snow drifts develop in topographic depressions such as valleys and gullies [49]. These snowdrifts can last through the summer, in particular when protected from melting by an insulating layer of plant detritus. This layer can develop during winter when the strong winds transport and deposit plant detritus together with snow.

Ramage et al. [65] identified 40 hydrologic catchments on Qikiqtaruk Island that drain into the surrounding ocean. Our study focuses on the catchments around the Ice Creek catchment in the southeastern part of the island (Figure 1). The Ice Creek catchment consists of two sub-catchments each approximately $1.5 \mathrm{~km}^{2}$ in size and draining from north to south into a fluvial plain. The maximum height of the catchment is $95 \mathrm{~m}$ above sea level in the north. Both catchments are cut by smaller valleys and gullies and characterized by rapid gully erosion as well as mass movements ranging from solifluction to rapid active layer detachments [66]. The occurrence of ice-rich permafrost and permafrost disturbances on the island as well as its location in the lowland tundra type and the long-term ongoing research make Qikiqtaruk a representative study site with respect to the pan-arctic scale.

\section{Data \& Methods}

In order to create maps of snow cover extent (SCE) and fractional snow cover (FSC), we used dense time-series of TSX as well as Landsat 8 imagery as input and in situ time-lapse camera as well as meteorological data for the assessment of TSX derived SCE and FSC. The workflow that we followed is presented in Figure 2.

\subsection{SAR Satellite Data}

We used dual cross-(VH/VV) and co-polarized (HH/VV) multi-orbit TSX time-series with acquisition dates between April and July from 2015 to 2017. TSX uses a right looking active phased array antenna that operates at an X-Band center frequency of $9.65 \mathrm{Ghz}$ with an orbital revisit time of 11 days. Using multi-orbit data from ascending and descending orbit headings allowed us to increase the revisit time to observe snowmelt in high temporal resolution. The incidence angles of the orbits at the image scene center varied between $25^{\circ}$ and $39^{\circ}$ with varying pixel spacing between 1.9 to $2.8 \mathrm{~m}$ in range and $6.6 \mathrm{~m}$ in azimuth. Though shadowing and layover can affect the quality of TSX data, the relief of Qikiqtaruk is low, meaning the influence of layover and shadow is generally minimal inland. We masked out the coastal areas with the steep cliffs since they are not representing delineated catchments and could introduce errors of shadow and layover. Examples of TSX backscatter and Landsat 8 images are shown in Figure 3. 


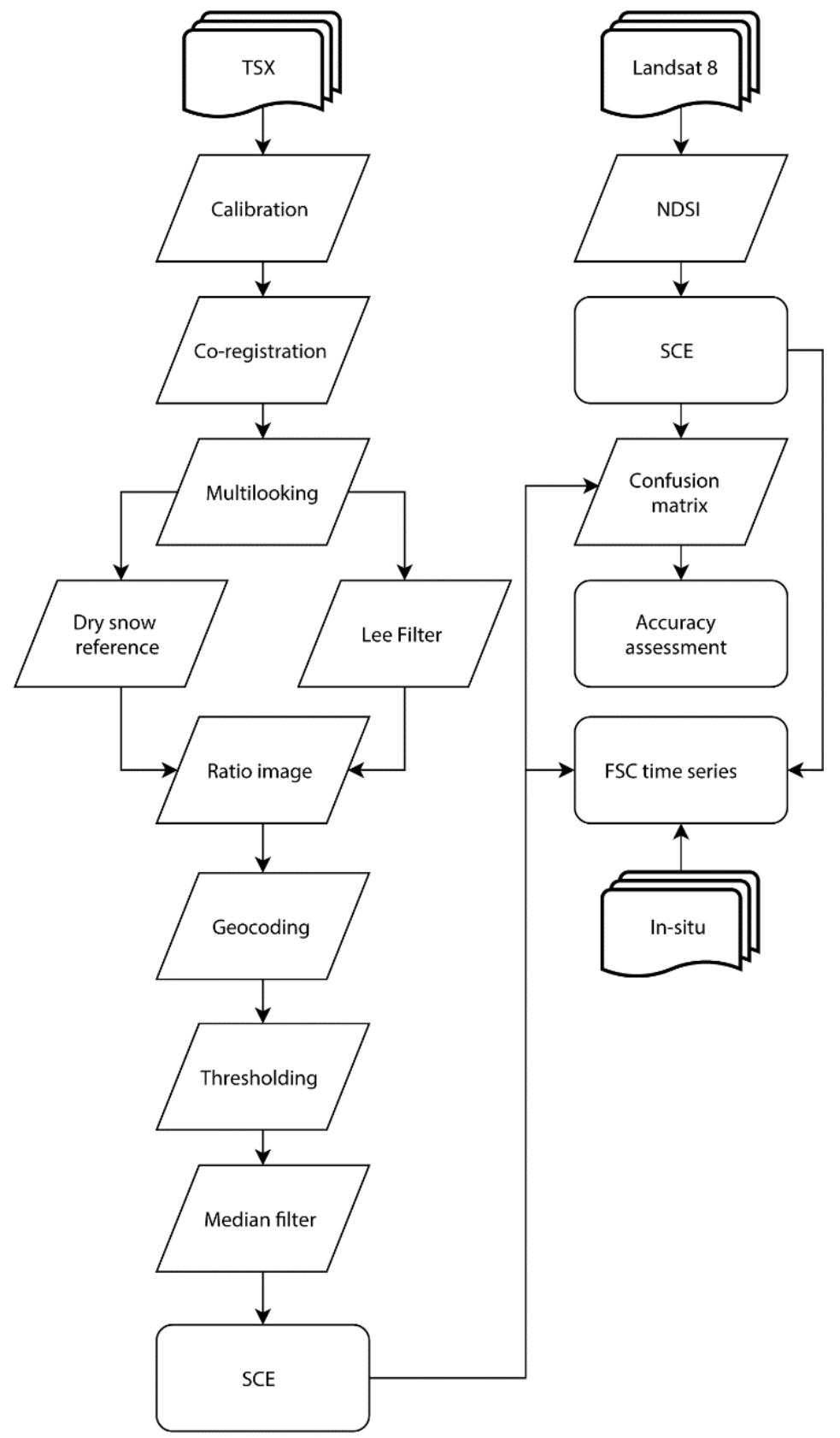

Figure 2. Data processing scheme for the optical Landsat 8 and TSX data. Layered objects represent input data, diamonds processing steps and rounded rectangles results. FSC = Fractional Snow Cover; NDSI = Normalized Difference Snow Index; SCE = Snow Cover Extent.

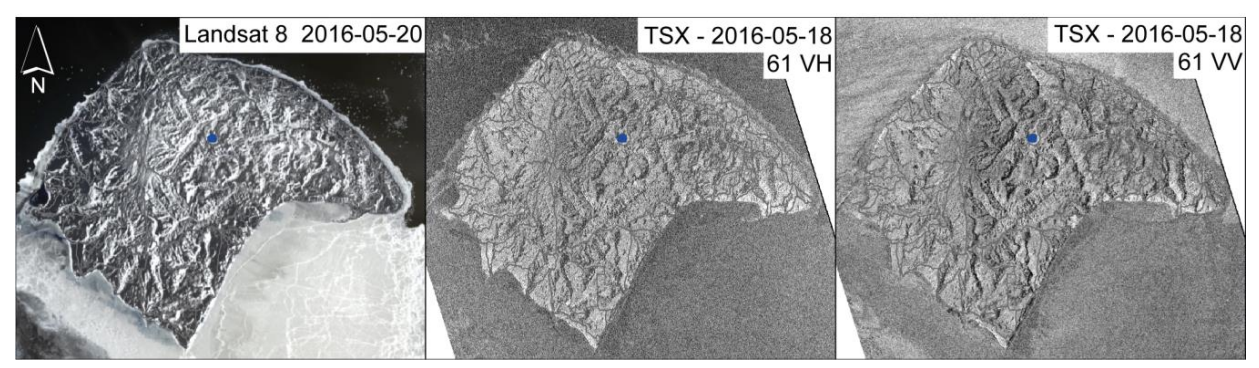

Figure 3. Examples of Landsat 8 (left), TerraSAR-X in VH (center), and TSX in VV (right) polarization. 


\subsection{Optical Satellite Data}

We used all available cloud-free Landsat 8 imagery from 2015 to 2017 between the months of April and July. In total, we used 20 Landsat 8 Operational Land Imager (OLI) acquisitions downloaded in processing Level-1 TP. Level-1 TP is the Standard Terrain Correction of the Landsat products, including radiometrically calibrated images that were orthorectified using ground control points and digital elevation models. We downloaded all acquisitions using the bulk download application from the USGS earth explorer service. The Landsat 8 OLI visible, near-infrared and shortwave infrared bands have a $30 \mathrm{~m}$ spatial resolution. We created quasi-true RGB composite imagery from every acquisition as a visual reference and additionally used the green and short wave infrared bands for SCE generation (see section "Snow Cover Extent generation from Landsat 8").

\subsection{In situ Time-Lapse Camera Data}

Time-lapse cameras were set up in the framework of the Helmholtz Young Investigators Group "COPER" and the "ShrubTundra" research projects in the spring of 2016 and 2017 as part of ongoing hydrological and phenological monitoring on the island. Five cameras acquired images at an hourly resolution in a northward facing aspect with a landscape field of view. One camera was set up for monitoring a hydrological flume at the outlet of the western Ice Creek catchment and acquired imagery at a three hourly resolution from the $24^{\text {th }}$ of April to the $20^{\text {th }}$ of July 2016 (Camera ID: TL2). Four phenological cameras (PC) were set up for the monitoring of phenology of vegetation communities at locations around the Ice Creek catchment (Camera IDs: PC2, PC3, PC5 and PC6). While camera TL2 represents snow dynamics of deeply incised valley locations, cameras PC2, PC3, PC5 and PC6 represent snow dynamics of upland tundra topography and vegetation of Qikiqtaruk. The time-lapse camera data were used for a ground based quality assessment of a TSX derived FSC time series. Photos that correspond to the TSX acquisition dates and time of day were used in the analysis when available, otherwise the closest date and time were chosen. The greatest difference between photos and TSX acquisition was a single day. The cameras were subject to disturbance by wildlife, active layer thaw and weather and, therefore, were not always operational, causing data gaps up to several days. Because of the remoteness of the study site, detailed in situ data on snow properties were not available to assess the impact of snow genesis on the backscatter signal. The time lapse cameras that we use for estimation of snow cover extent are a cost-effective tool in this environment. Visual estimations of percent cover are a common approach in ecological studies [67]. The results present very valuable insights into the melt dynamics in the camera footprint that could not be obtained otherwise and can be related to the satellite based measurements.

In addition, meteorological records from an automated weather station run by Environment Canada on Simpson Point on the southeastern spit of the island (World Meteorological Organization ID: 715010) were used to assess the FSC time series in 2015, 2016, and 2017. The data is available at a daily temporal resolution, recording mean, minimum and maximum daily air temperature.

\subsection{Snow Cover Extent from TerraSAR-X}

To generate SCE maps from TSX we adapted the workflow suggested by Nagler and Rott [40] and calculated ratio images of backscatter intensity calibrated to radar brightness in sigma nought $(\sigma 0)$ as well as speckle-filtered, see details below, between an averaged dry snow reference image from TSX winter scenes (See Table S1) and melting snow scenes from spring/summer with the same orbital configuration. The reduced backscatter signal of melting snow, as well as the increased backscatter of frozen ice layers, is the basis for a threshold segmentation that efficiently differentiates between wet snow or ice layers and dry snow or no snow. While this method was originally developed for C-Band of ERS-1 data and was further improved and adapted for ERS-2, RADARSAT-1, ENVISAT ASAR and Sentinel-1 data $[40,68,69]$, it was also applied for X-Band data from TSX and COSMOSkyMed data $[38,70,71]$. 
The backscatter intensity of images acquired during the spring show notable differences between acquisitions caused by drifting sea ice and snowmelt that reduce the quality of co-registration when using cross-correlation. For a given acquisition orbit, all images therefore were co-registered to sub-resolution accuracy with respect to a pre-selected master image using the highly accurate orbital information from TSX and ellipsoidal heights. In order to avoid early season effects of snowmelt with resulting high soil moisture variations and beginning vegetation dynamics, we chose mid-summer acquisitions (July) as the master images when environmental conditions had stabilized.

By applying $3 \times 9$ multilooking to the intensity images, we address the speckle effect inherent to SAR imagery obtaining a roughly square pixel size of around $20 \mathrm{~m}$ (Table 1). We further reduced the effect of speckle by applying a Lee filter with a window size $5 \times 5$ pixel [72].

Table 1. Information on TSX orbits used in this study. RA = Range, $A Z=$ Azimuth. The incidence angle $\theta$ refers to the image scene center. Winter scenes are defined by TSX acquisition dates with expected snowmelt before the $1^{\text {st }}$ of May; spring/summer scenes are defined as all TSX scenes with dates after the $1^{\text {st }}$ of May.

\begin{tabular}{ccccccccc}
\hline \multicolumn{3}{c}{ Acquisition Time } & \multicolumn{1}{c}{ No. of Scenes } \\
\hline Orbit No. & UTC & Local Time & Orbit Heading & $\begin{array}{c}\text { Incidence } \\
\text { Angle } \boldsymbol{\theta}\end{array}$ & $\begin{array}{c}\text { Pixel Spacing } \\
\text { RA/AZ }\end{array}$ & Polarization & Winter & Summer \\
\hline 24 & $16: 08$ & $9: 08$ & Descending & $31^{\circ}$ & $2.3 / 6.6$ & $\mathrm{HH} / \mathrm{VV}$ & 7 & 22 \\
61 & $2: 26$ & $19: 26$ & Ascending & $32^{\circ}$ & $2.2 / 6.6$ & $\mathrm{VV} / \mathrm{VH}$ & 5 & 25 \\
115 & $15: 59$ & $8: 59$ & Descending & $39^{\circ}$ & $1.9 / 6.6$ & $\mathrm{VV} / \mathrm{VH}$ & 4 & 16 \\
137 & $2: 35$ & $19: 35$ & Ascending & $39^{\circ}$ & $1.9 / 6.6$ & $\mathrm{HH} / \mathrm{VV}$ & 2 & 20 \\
152 & $2: 18$ & $19: 18$ & Ascending & $25^{\circ}$ & $2.8 / 6.6$ & $\mathrm{HH} / \mathrm{VV}$ & 8 & 29 \\
\hline
\end{tabular}

We tested the Lee [72] and Frost [73] filters to address the speckle effect within the intensity images for their performance for SCE generation. Figure 4 shows the optical reference data from Landsat 8 and the results from TSX with a two-day-later acquisition date and differing filter techniques. The differences between the Frost and the Lee Filter were insignificant; however, the processing time for the moving window calculation of the Frost filter was much longer. We therefore decided to use the Lee Filter with a $5 \times 5$ window for all SCE generation, since it satisfactorily removes speckle related effects from the SCE maps.

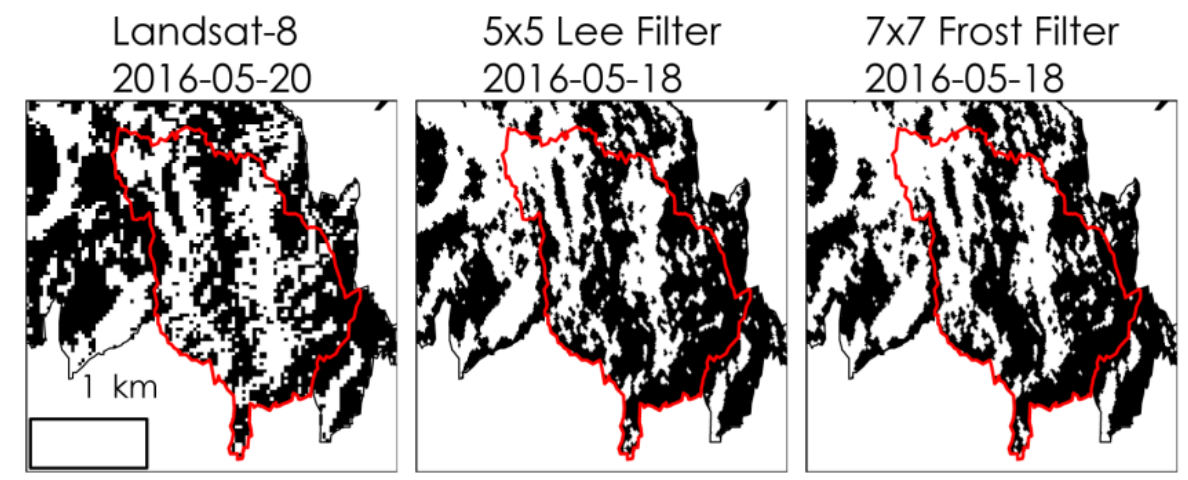

Figure 4. Comparison of filter methods for SCE generation. White pixels represent snow. The red line represents the Ice Creek catchment limit on the southeastern part of Qikiqtaruk.

We computed the $\sigma 0$-ratios between the melting snow images and the dry snow reference separately for each polarization channel before transforming the ratio images to logarithmic scale $(\mathrm{dB})$. We then geocoded the ratio images using the intermediate DEM product from the TanDEM-X mission with a spatial resolution of $12.5 \mathrm{~m}$ and a vertical accuracy of $2 \mathrm{~m}$ [74]. The DEM was created by DLR using several TerraSAR-X scenes from winter 2010 and 2011 and the Height Error Map provided with 
the DEM product states a mean error of $0.72 \pm 0.2 \mathrm{~m}$ within the area of the hydrological catchments. We tested the application of two thresholds on TSX ratio images. We first used a threshold of $-2 \mathrm{~dB}$ for $\mathrm{VH}$ and $\mathrm{HH}$ and $-2.3 \mathrm{~dB}$ for $\mathrm{VV}$ data as reported in Schellenberger [39], with values below the threshold showing the presence of wet snow. We also applied a threshold of $1 \mathrm{~dB}$ on all TSX ratio images, with values below 1 representing the presence of snow with ice layers. We filtered the thresholding results using a median filter with a window size of $5 \times 5$ pixels.

\subsection{Snow Cover Extent from Landsat 8}

We applied the spectral band ratio of the Normalized Difference Snow Index (NDSI) to generate SCE maps from Landsat. The NDSI is a commonly applied ratio index for snow detection from optical sensor data [75], using the contrast in the visible green versus the shortwave infrared band reflectance. We applied the NDSI with OLI bands 3 and 6 , and the threshold technique with NDSI $>0.4$ to binary-classify snow presence and absence with greater or less than $50 \%$ snow cover at pixel-level, respectively [76]. In optical remote sensing pixels with NDSI values greater than 0.4 , they have been found to be more than $50 \%$ snow covered [77].

\subsection{Accuracy Assessment of TerraSAR-X Snow Cover Extent}

Confusion or error matrices are commonly used to assess the quality of classified spatial data from different data sources, at the same time [78]. In order to estimate the quality of TSX derived SCE, we created confusion matrices between a TSX SCE and the corresponding Landsat 8 SCE. We chose corresponding Landsat 8 SCE with acquisition dates not further apart than \pm 3 days from the TSX SCE. We used 5000 accuracy assessment points for every pair, which were proportionally distributed between the classes of "snow" and "no snow" in a stratified random approach. We averaged the final results from 100 iterations of this accuracy assessment. The results include the users, producers and overall accuracies. These values give an indication of the reliability of the TSX maps, with users accuracy indicating that TSX is detecting snow where Landsat 8 does not, and producers accuracy indicating that TSX is not detecting snow when Landsat 8 is, overall accuracy is a weighted measure that indicates the general occurrence of errors.

\subsection{Fractional Snow Cover Time Series Analysis}

We calculated the fractional wet snow cover (hereafter referred to as FSC) from the generated SCE maps in percent (\%) for (1) all small catchments on the island and (2) for the entire island by merging all individual catchments into a single area. We resampled and aligned the TSX SCE to the $30 \mathrm{~m}$ spatial resolution of the Landsat 8 SCE. The footprints of the TSX orbits 152, 137 and 24 do not cover the entire western part of the island. We calculated the fraction of snow pixels within a catchment for every SCE with regard to the total number of pixels within the catchments. We used the WGS UTM Zone 7N coordinate system for all map outputs. To validate the time series of TSX FSC, we analyzed in situ data from the time lapse cameras in and around the Ice Creek catchment (Table S2). For each time-lapse image, the snow cover within the field of view was estimated interactively by an independent visual interpretation of the photo by three different individuals. We then averaged the three estimations for every image acquisition. Additionally, for the cameras observing phenology in 2017 we averaged the estimations of the four available cameras per date in order to obtain a valid representation of the upland tundra type of the island.

\section{Results}

\subsection{Evaluation of Backscatter Time Series}

The variation of backscatter in winter and spring at a site within the Ice Creek catchment is shown in Figure 5. Variations of backscatter before May in the expected pre-melt phase are small. In all years and polarizations, a drop of backscatter intensity is recorded in early to mid-May during expected 
peak snowmelt. This is followed by a strong and rapid increase of backscatter that goes above the backscatter signature of the stable pre-melt phase.

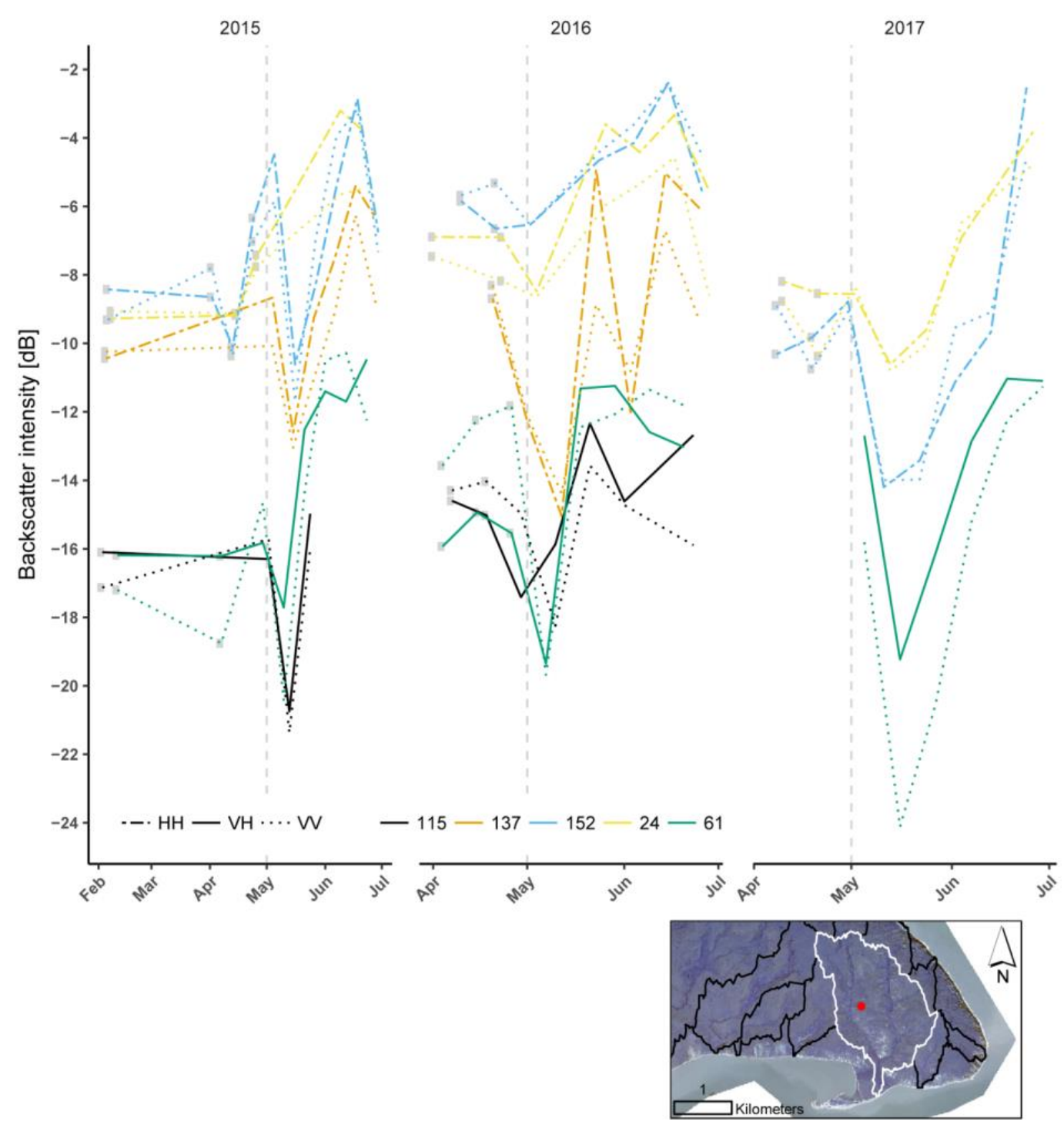

Figure 5. Backscatter time series of TSX orbits in the Western Ice Creek catchment. The red dot indicates the footprint of the extracted backscatter.

\subsection{Evaluation of TSX Snow Cover Extent}

The visual assessment of the TSX derived SCE from two different thresholds and from three polarization channels demonstrates the influence of polarization in X-Band on the application of monitoring SCE in an Arctic environment (Figures 6-9 and Figures S1-S6). Quantitative comparison of seven VH-, eight VV- and 15 HH based TSX derived SCE maps with paired optical SCE maps showed that the $\mathrm{VH}$ polarization channel performed best and most consistently in detecting snow cover during the snowmelt period (Table 2). We achieved the highest overall accuracies when using VH polarized images. The incidence angle and time difference between paired TSX and optical acquisitions did not show a clear effect on the overall accuracy. The overall accuracy of the SCE maps from VH data generally showed a higher agreement later in the snowmelt season except for the TSX acquisition from the $10^{\text {th }}$ of May 2016. The other polarizations did not show a clear influence of time on the overall accuracy of SCE (Table 2). 
Table 2. Confusion matrix results from the comparison of TerraSAR-X and Landsat 8-derived SCE during snow melt for the three polarizations and for the two applied thresholds (TH) -2 and $1 \mathrm{~dB}$. $\mathrm{U}=$ Users accuracy, $\mathrm{P}=$ Producers accuracy, $\mathrm{O}=$ Overall accuracy.

\begin{tabular}{|c|c|c|c|c|c|c|c|c|c|c|}
\hline \multirow[b]{2}{*}{ TSX Date } & \multirow[b]{2}{*}{ Polarization } & \multirow[b]{2}{*}{ Orbit } & \multirow[b]{2}{*}{ Incidence Angle } & \multirow[b]{2}{*}{ Landsat Date } & \multicolumn{2}{|c|}{$\mathbf{U}$} & \multicolumn{2}{|c|}{$\mathbf{P}$} & \multicolumn{2}{|c|}{$\mathbf{O}$} \\
\hline & & & & & TH-2 & TH1 & TH-2 & TH1 & TH-2 & TH1 \\
\hline 15 May 2015 & $\mathrm{HH}$ & 137 & 39 & 16 May 2015 & 0.78 & 0.78 & 0.61 & 0.68 & 0.68 & 0.68 \\
\hline 16 May 2015 & $\mathrm{HH}$ & 152 & 25 & 16 May 2015 & 0.78 & 0.73 & 0.79 & 0.86 & 0.75 & 0.72 \\
\hline 26 May 2015 & $\mathrm{HH}$ & 137 & 39 & 25 May 2015 & 0.95 & 0.95 & 0.89 & 0.91 & 0.86 & 0.87 \\
\hline 28 June 2016 & $\mathrm{HH}$ & 24 & 31 & 28 June 2016 & 1.00 & 1.00 & 0.78 & 0.78 & 0.78 & 0.78 \\
\hline 24 June 2017 & $\mathrm{HH}$ & 152 & 25 & 24 June 2017 & 0.98 & 0.99 & 0.87 & 0.88 & 0.85 & 0.86 \\
\hline 26 June 2017 & $\mathrm{HH}$ & 24 & 31 & 24 June 2017 & 0.96 & 0.96 & 0.36 & 0.37 & 0.36 & 0.37 \\
\hline 7 July 2017 & $\mathrm{HH}$ & 24 & 31 & 8 July 2017 & 1.00 & 1.00 & 0.59 & 0.59 & 0.59 & 0.59 \\
\hline 24 May 2015 & VH & 115 & 39 & 25 May 2015 & 0.98 & 0.98 & 0.89 & 0.89 & 0.88 & 0.88 \\
\hline 23 June 2015 & VH & 61 & 32 & 26 June 2015 & 1.00 & 1.00 & 0.98 & 0.98 & 0.98 & 0.98 \\
\hline 18 May 2016 & VH & 61 & 32 & 20 May 2016 & 0.86 & 0.86 & 0.67 & 0.68 & 0.74 & 0.74 \\
\hline 21 May 2016 & VH & 115 & 39 & 20 May 2016 & 0.71 & 0.72 & 0.97 & 0.97 & 0.75 & 0.76 \\
\hline 12 July 2016 & VH & 61 & 32 & 14 July 2016 & 1.00 & 1.00 & 0.98 & 0.98 & 0.98 & 0.98 \\
\hline 15 July 2016 & VH & 115 & 39 & 14 July 2016 & 1.00 & 1.00 & 1.00 & 1.00 & 1.00 & 1.00 \\
\hline 15 May 2015 & VV & 137 & 39 & 16 May 2015 & 0.80 & 0.77 & 0.53 & 0.53 & 0.65 & 0.63 \\
\hline 16 May 2015 & VV & 152 & 25 & 16 May 2015 & 0.78 & 0.72 & 0.77 & 0.85 & 0.74 & 0.71 \\
\hline 24 May 2015 & VV & 115 & 39 & 25 May 2015 & 0.96 & 0.96 & 0.46 & 0.47 & 0.48 & 0.49 \\
\hline 26 May 2015 & VV & 137 & 39 & 25 May 2015 & 0.95 & 0.95 & 0.89 & 0.88 & 0.86 & 0.84 \\
\hline 23 June 2015 & VV & 61 & 32 & 26 June 2015 & 1.00 & 1.00 & 0.83 & 0.84 & 0.83 & 0.83 \\
\hline 18 May 2016 & VV & 61 & 32 & 20 May 2016 & 0.80 & 0.81 & 0.53 & 0.55 & 0.64 & 0.65 \\
\hline 21 May 2016 & VV & 115 & 39 & 20 May 2016 & 0.77 & 0.78 & 0.82 & 0.82 & 0.75 & 0.75 \\
\hline 28 June 2016 & VV & 24 & 31 & 28 June 2016 & 1.00 & 1.00 & 0.58 & 0.58 & 0.58 & 0.58 \\
\hline 12 July 2016 & VV & 61 & 32 & 14 July 2016 & 1.00 & 1.00 & 0.67 & 0.67 & 0.67 & 0.67 \\
\hline 15 July 2016 & VV & 115 & 39 & 14 July 2016 & 1.00 & 1.00 & 0.91 & 0.92 & 0.91 & 0.92 \\
\hline 24 June 2017 & VV & 152 & 25 & 24 June 2017 & 0.98 & 0.98 & 0.78 & 0.83 & 0.77 & 0.82 \\
\hline 26 June 2017 & VV & 24 & 31 & 24 June 2017 & 0.95 & 0.96 & 0.27 & 0.28 & 0.27 & 0.28 \\
\hline 7 July 2017 & VV & 24 & 31 & 8 July 2017 & 1.00 & 1.00 & 0.46 & 0.47 & 0.46 & 0.47 \\
\hline
\end{tabular}

Results from confusion matrices before snow melt are shown in Table 3. The correspondence between optical and TSX derived SCE is very low for the users accuracy and high for the producers accuracy (Table 3).

Table 3. Confusion matrix results from the comparison of TerraSAR-X and Landsat 8-derived SCE before peak snow melt for the three polarizations. $\mathrm{U}=$ Users accuracy, $\mathrm{P}=$ Producers accuracy, $\mathrm{O}=$ Overall accuracy.

\begin{tabular}{ccccccccccc}
\hline & & & & & \multicolumn{2}{c}{ U } & \multicolumn{2}{c}{ O } \\
\hline TSX Date & Polarization & Orbit & Incidence Angle & Landsat Date & TH-2 & TH0 & TH-2 & TH0 & TH-2 & TH0 \\
\hline 12 May 2016 & HH & 137 & 39 & 11 May 2016 & 0.05 & 0.05 & 0.82 & 0.89 & 0.91 & 0.78 \\
10 May 2016 & VH & 115 & 39 & 11 May 2016 & 0.01 & 0.01 & 0.87 & 0.88 & 0.23 & 0.23 \\
10 May 2016 & VV & 115 & 39 & 11 May 2016 & 0.01 & 0.02 & 0.91 & 0.89 & 0.33 & 0.32 \\
12 May 2016 & VV & 137 & 39 & 11 May 2016 & 0.05 & 0.06 & 0.82 & 0.81 & 0.90 & 0.88 \\
\hline
\end{tabular}

The results of SCE maps from optical and TSX data are presented in the following, with Figures 6 and 7 showing SCE maps derived from thresholds $-2 \mathrm{~dB}$ and Figures 8 and 9 showing the results from the threshold $1 \mathrm{~dB}$. The SCE maps from orbit 61 and 115 generated from the literature derived thresholds of -2 and $-2.3 \mathrm{~dB}$ for $\mathrm{VH}$ and $\mathrm{VV}$ polarizations, respectively, showing a strong under estimation of TSX SCE compared to Landsat 8 SCE (Figures 6 and 7). Figure 6 is the comparison of $\mathrm{VH}$ and VV from orbit 61 from May $18^{\text {th }}$ to $20^{\text {th }}$ and demonstrates a clear underestimation of SCE. Wet snow cover was detected in low-lying areas in the delineated catchments in late May (Figure 8, second row). 


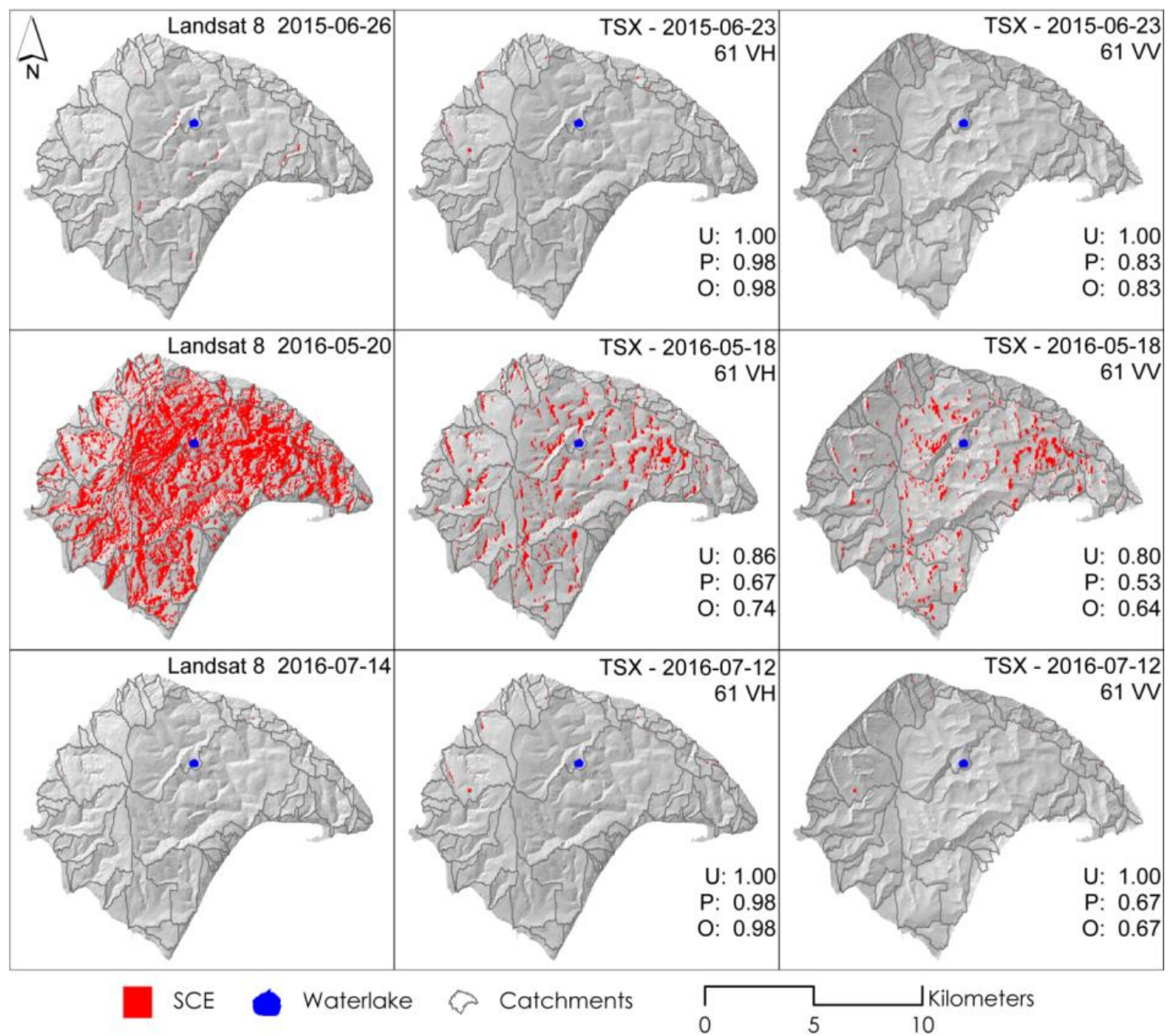

Figure 6. Comparison of Landsat 8 SCE (left panels) and corresponding TSX SCE derived using a threshold of $-2 \mathrm{~dB}$ on the $\mathrm{VH}$ (middle panels) and $-2.3 \mathrm{~dB}$ on the VV (right panels) polarized channels of orbit 61 from three dates in 2015 (first row) and 2016 (third and fourth row). Also shown are the results of the accuracy assessment, $\mathrm{U}=$ Users accuracy, $\mathrm{P}=$ Producers accuracy, $\mathrm{O}=$ Overall accuracy.

In Figure 7, the orbit 115 also shows a strong underestimation of SCE very similar to orbit 61. Snow is detected only in low-lying valley areas in late May. The pre-melt snow cover images in from 11 May 2016 demonstrate the invisibility of the dry snow cover in TSX for both thresholds. 


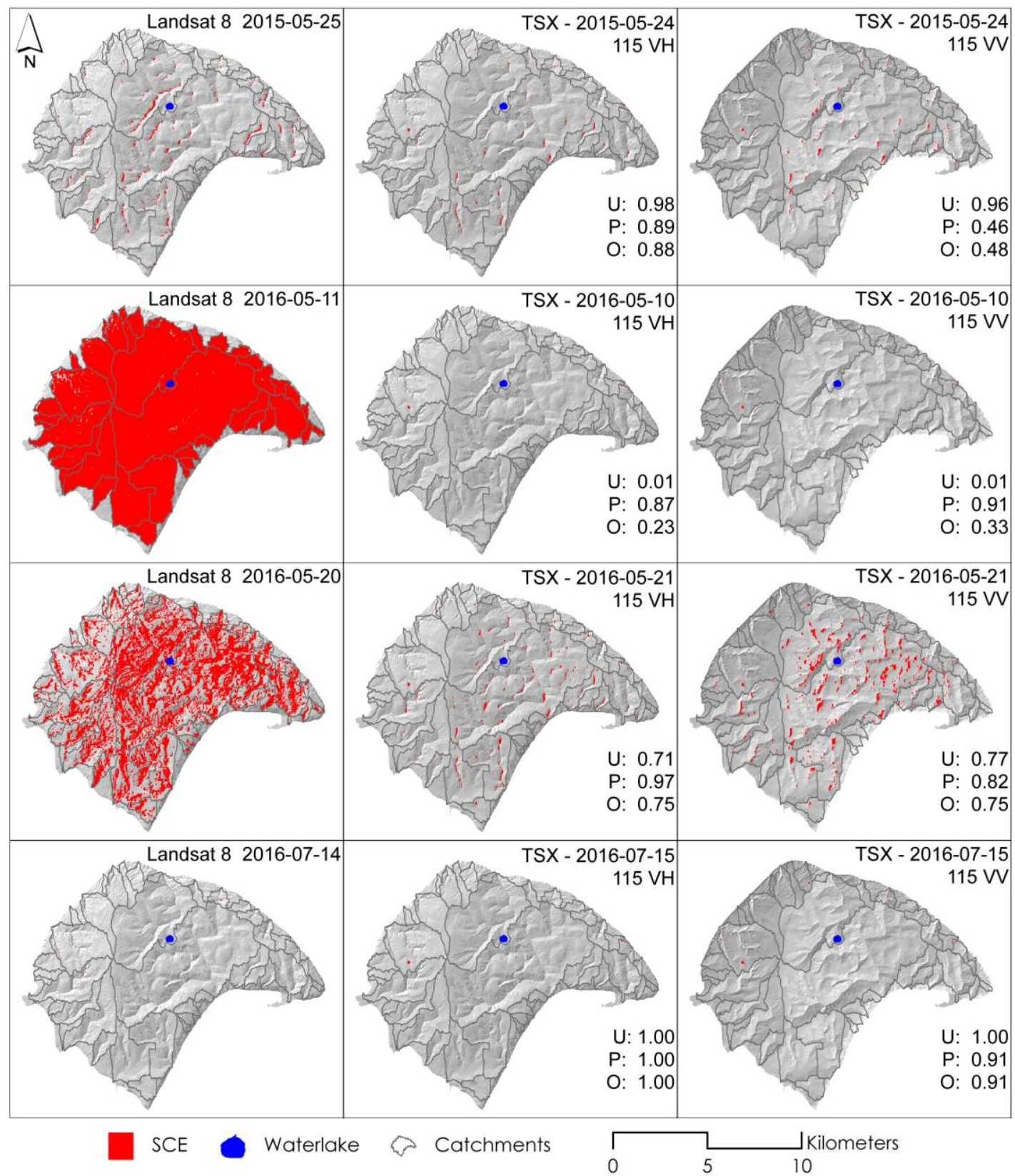

Figure 7. Comparison of Landsat 8 SCE (left panels) and corresponding TSX SCE derived using a threshold of $-2 \mathrm{~dB}$ on the $\mathrm{VH}$ (middle panels) and $-2.3 \mathrm{~dB}$ on the VV (right panels) polarized channels of orbit 115 from four dates in 2015 (first row) and 2016 (second, fourth and fifth row). Also shown are the results of the accuracy assessment, $\mathrm{U}=$ Users accuracy, $\mathrm{P}=$ Producers accuracy, $\mathrm{O}=$ Overall accuracy.

The comparison of TSX derived VH polarized SCE maps using the $1 \mathrm{~dB}$ threshold from orbits 61 and 115 and optical derived SCE maps highlight the spatial patterns of agreement between the two data sources (Figures 8 and 9). Figure 8 represents a comparison of VH and VV polarized TSX SCE from orbit 61 and the corresponding Landsat 8 SCE at three different stages of snowmelt in 2015 and 2016. The Landsat 8 SCE map from the $26^{\text {th }}$ of June 2015 shows only a few remaining and small snow patches in low-lying valleys. On the $23^{\text {rd }}$ of June 2015, the TSX in VH showed elongated single patches of snow distributed sparsely over the island while the VV channel detected larger connected areas of snow cover except in the central part of the island. During peak snowmelt, the TSX derived SCE from the $18^{\text {th }}$ of May 2016 showed denser snow cover than the Landsat 8 SCE from the $20^{\text {th }}$ of May 
2016. In particular, TSX detected denser snow cover on the higher and flat terrain in the center of the island and northwest of the Ice Creek catchment (Figure 8, second row). The later stage snowmelt maps also show good agreement between TSX and optically derived products (Figure 8, third row). The general pattern of overestimation of VV is evident in all VV polarized SCE maps in Figure 8 and also in Figure 9.

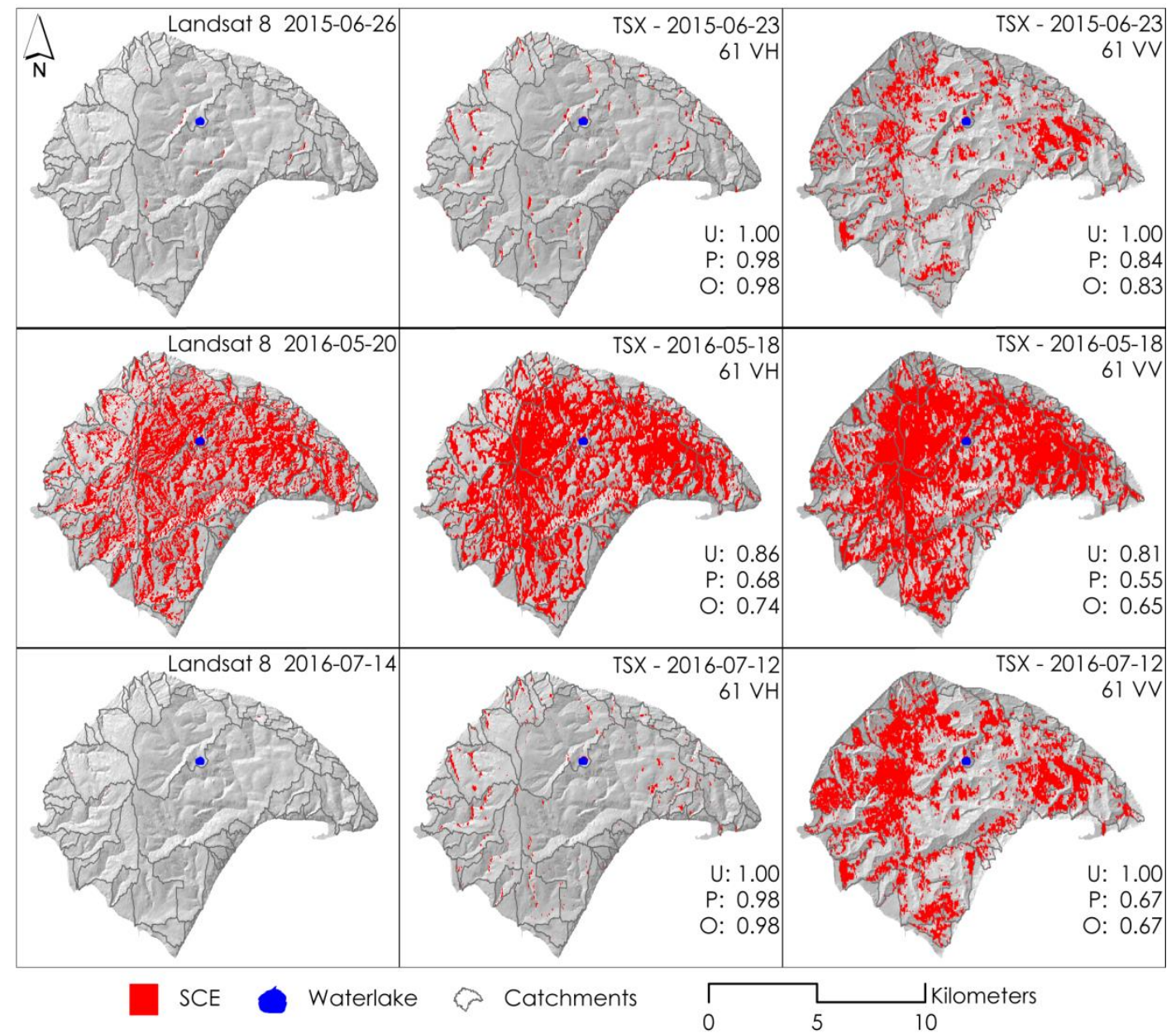

Figure 8. Comparison of Landsat 8 SCE (left panels) and corresponding TSX SCE derived using a threshold of $1 \mathrm{~dB}$ on the VH (middle panels) and VV (right panels) polarized channels of orbit 61 from three dates in 2015 (first row) and 2016 (third and fourth row). Also shown are the results of the accuracy assessment, $\mathrm{U}=$ Users accuracy, $\mathrm{P}=$ Producers accuracy, $\mathrm{O}=$ Overall accuracy.

In Figure 9, the 25 May 2015 Landsat 8 SCE map shows several elongated snow banks remaining on the island. The corresponding TSX result from a day earlier shows the same pattern in VH but additionally detects what appears to be wet snow patches with a more scattered distribution on the western part of the island. The VV channel again shows strong overestimation of SCE almost in all areas of the island. The early melt, as shown in the second row of Figure 9, is not captured well by TSX in both polarizations, while the overall accuracy is considerably higher in the late snowmelt season of 2016. 


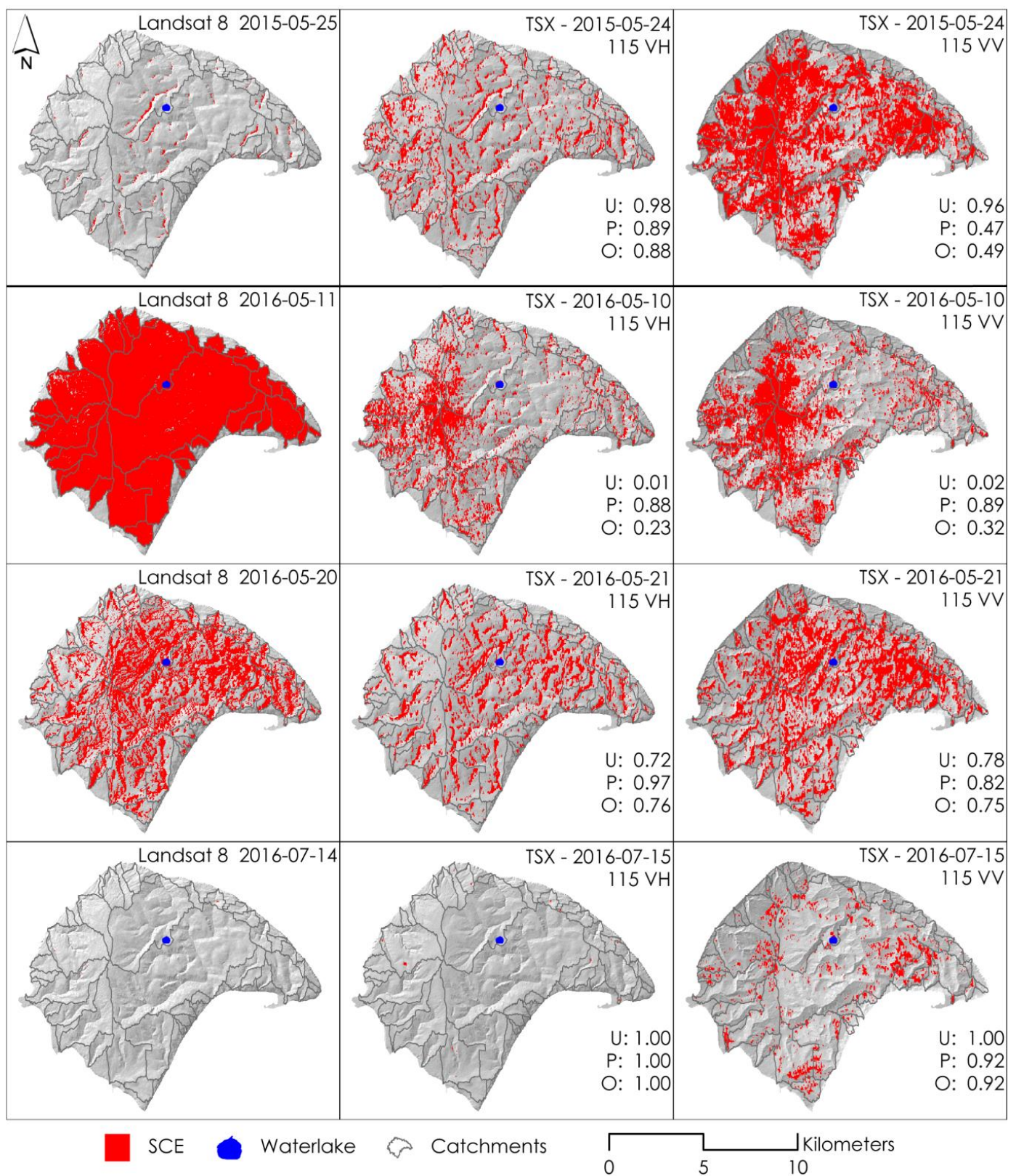

Figure 9. Comparison of Landsat 8 SCE (left panels) and corresponding TSX SCE derived using a threshold of $1 \mathrm{~dB}$ on the $\mathrm{VH}$ (middle panels) and VV (right panels) polarized channels of orbit 115 from four dates in 2015 (first row) and 2016 (second, fourth and fifth row). Also shown are the results of the accuracy assessment, $\mathrm{U}=$ Users accuracy, $\mathrm{P}=$ Producers accuracy, $\mathrm{O}=$ Overall accuracy.

\subsection{Time Series of Fractional Snow Cover in All Catchments}

Building on the results of the accuracy assessment, all orbits with $\mathrm{VH}$ polarization were chosen to examine the snowmelt dynamics in 2015, 2016, and 2017. Figure 10 shows a time series of FSC products calculated for the unified catchment area from Landsat 8 and VH polarized TSX derived SCE using the threshold of $1 \mathrm{~dB}$ as well as the corresponding minimum, mean and maximum daily air temperatures. In all three years, the TSX derived FSC showed good agreement with the optical Landsat 8 FSC and both data sources show a typical snowmelt pattern with increasing air temperatures (Figure 7). The agreement between TSX and Landsat 8 FSC data was lowest early in the snowmelt period (April to early May). Due to the independence of TSX to atmospheric conditions and cloud cover, the temporal resolution of TSX was higher in all years particularly in the phase of rapid snow cover decline from mid-May to June. 

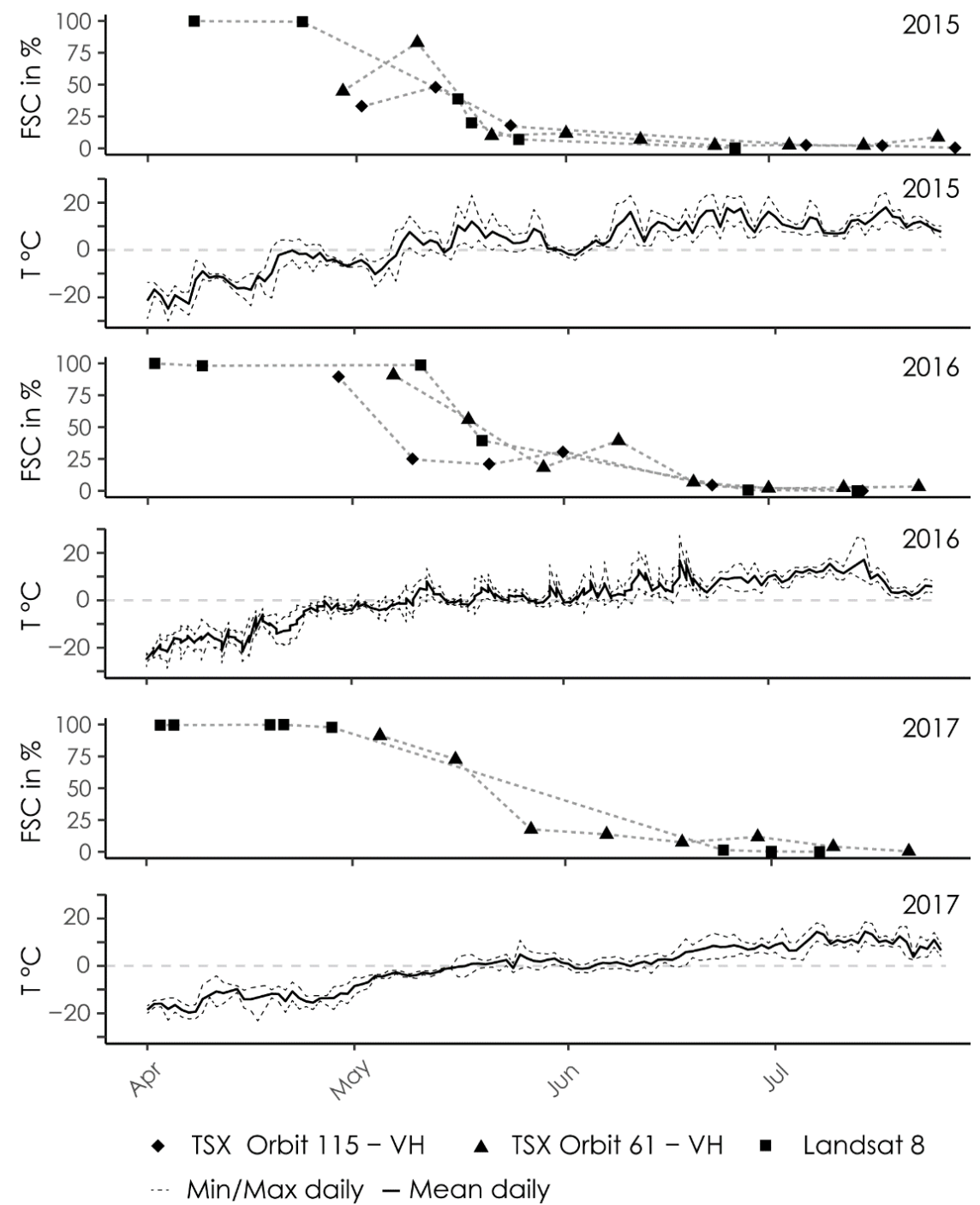

Figure 10. Time series of fractional snow cover (FSC) extent and air temperature of Qikiqtaruk from Landsat 8 and VH polarized TSX data from the orbits 115 and 61 for the years 2015, 2016, and 2017.

In 2015, the TSX FSC was below 50\% in the beginning of May and increased to $75 \%$ in mid-May when there was no Landsat 8 acquisition. Maximum air temperatures were above $0{ }^{\circ} \mathrm{C}$ early in mid to late-April before falling below around $-5^{\circ} \mathrm{C}$ for about 2 weeks, which corresponds to low snow cover observed by TSX in early May. Both TSX datasets show an increase in FSC followed by a sharp drop to around 10\% FSC at the beginning of June followed by a slow gradual decrease of FSC to $0 \%$ in July, which is visible in all datasets. In 2016, both TSX orbits showed nearly $100 \%$ FSC within the catchment areas in the beginning of May. TSX derived FSC calculated from orbit 61 then showed a strong gradual decrease to around $25 \%$ at the end of May while FSC calculated from orbit 115 showed a sharp drop to around $25 \%$ in early May. The FSC derived from Landsat 8 imagery shows a sharp drop from $100 \%$ FSC in early to about $30 \%$ in mid-May. In the late stage of snowmelt, all datasets show FSC of approximately $5 \%$. The air temperature in 2016 was stable around $0{ }^{\circ} \mathrm{C}$ for almost the entire month of May, but shows two peaks in early and mid-May that correspond to sharp drops in snow cover in Landsat 8 and TSX orbit 61.

Air temperatures in 2017 showed a gradual increase to $0{ }^{\circ} \mathrm{C}$ by mid-May and a corresponding gradual decrease in TSX derived FSC. There was approximately a 2-month gap in successful Landsat 8 acquisitions in 2017. 


\subsection{Time Series of Fractional Snow Cover in Three Small Catchments}

Figure 11 shows the time series of fractional snow cover in the Ice Creek catchment in 2016 as captured from different data sources. The six available acquisitions from Landsat 8 show the beginning snowmelt after the $9^{\text {th }}$ of May with a sharp drop to about $50 \%$ within a week and a more gradual retreat of the snow cover to about $5 \%$ by the $27^{\text {th }}$ of June. The SCE from orbit 61 recorded wet snow on the $9^{\text {th }}$ of May at about $85 \%$ and showed a reduction of FSC at a relatively constant rate to about $20 \%$ in 3 weeks by the end of June. An increase of FSC to $30 \%$ is recorded with the next acquisition in early June, followed by a reduction to about $10 \%$ around the $20^{\text {th }}$ of June followed by a slow decrease to $5 \%$ or less by the end of June. The SCE from orbit 115 shows a rapid decrease in FSC from around $80 \%$ to about $20 \%$ in a little more than a week between the $29^{\text {th }}$ of April and the $9^{\text {th }}$ of May. This coincides with the presented results in Figure 10 for the entire island and below $0{ }^{\circ} \mathrm{C}$ minimum air temperatures and the morning acquisition of this orbit. A slight increase to around 25\% FSC is followed by a gradual decrease to less than $5 \%$ by the end of June. The in situ imagery, collected in the lower end of the ice creek valley within steeper valley topography, show snowmelt beginning around the $9^{\text {th }}$ of May and a decrease of FSC to about $60 \%$ around the $17^{\text {th }}$ of May in less than 2 weeks. After that, FSC decreases at a faster rate to about $25 \%$ in only a few days before a more gradual melt reduces FSC to $0 \%$ on the $1^{\text {st }}$ of July.

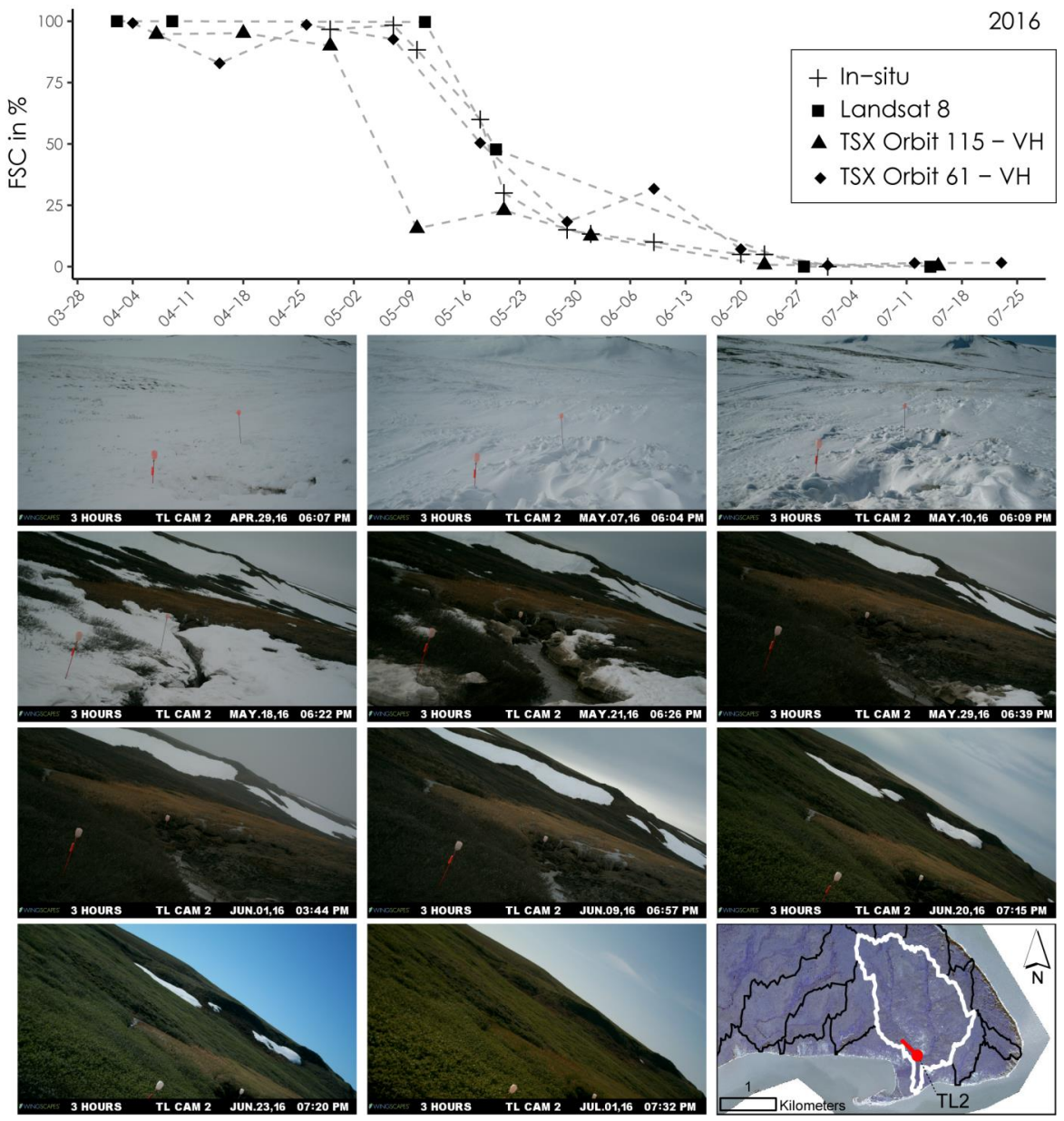

Figure 11. Top graph: Fractional snow cover from time lapse (in situ), Landsat 8 and TerraSAR-X (TSX) imagery in 2016 in the Ice Creek catchment (white outline in the map inlet on lower right). Dates on the $x$-axis show month-day. Time-lapse imagery is from Camera TL2 and is located in the lower Ice Creek. It's location (red dot) and viewing direction (red line) is indicated in the inset map on the lower right. Please note that the camera was unstable and moved between images because of ground thaw. Please note that the acquisition time of orbit 115 is in the morning, potentially affected by refreezing snow layers in early May. 
Figure 12 shows the FSC time series for the year 2017 of a small catchment southeast of Ice Creek as observed from in situ Landsat 8 and TSX data. The Landsat 8-derived FSC is mainly from before or after the main snowmelt period. Therefore, the decrease in FSC appears gradual between the $1^{\text {st }}$ of May and the middle of June from 100\% to below 25. The TSX derived SCE from orbit 61 detects wet snow cover in early June with an FSC of approximately $60 \%$ and decreases until the end of May gradually to about $20 \%$. Until the end of June, the FSC further decreases at a lower speed to about $5 \%$ and to $0 \%$ until the end of July. The in situ data collected from time lapse cameras that represent only upland areas of the watersheds show a rapid decrease in FSC from $80 \%$ to $20 \%$ in the first 2 weeks of May. At the end of May, FSC is below 5\% and by early June no snow is detected.
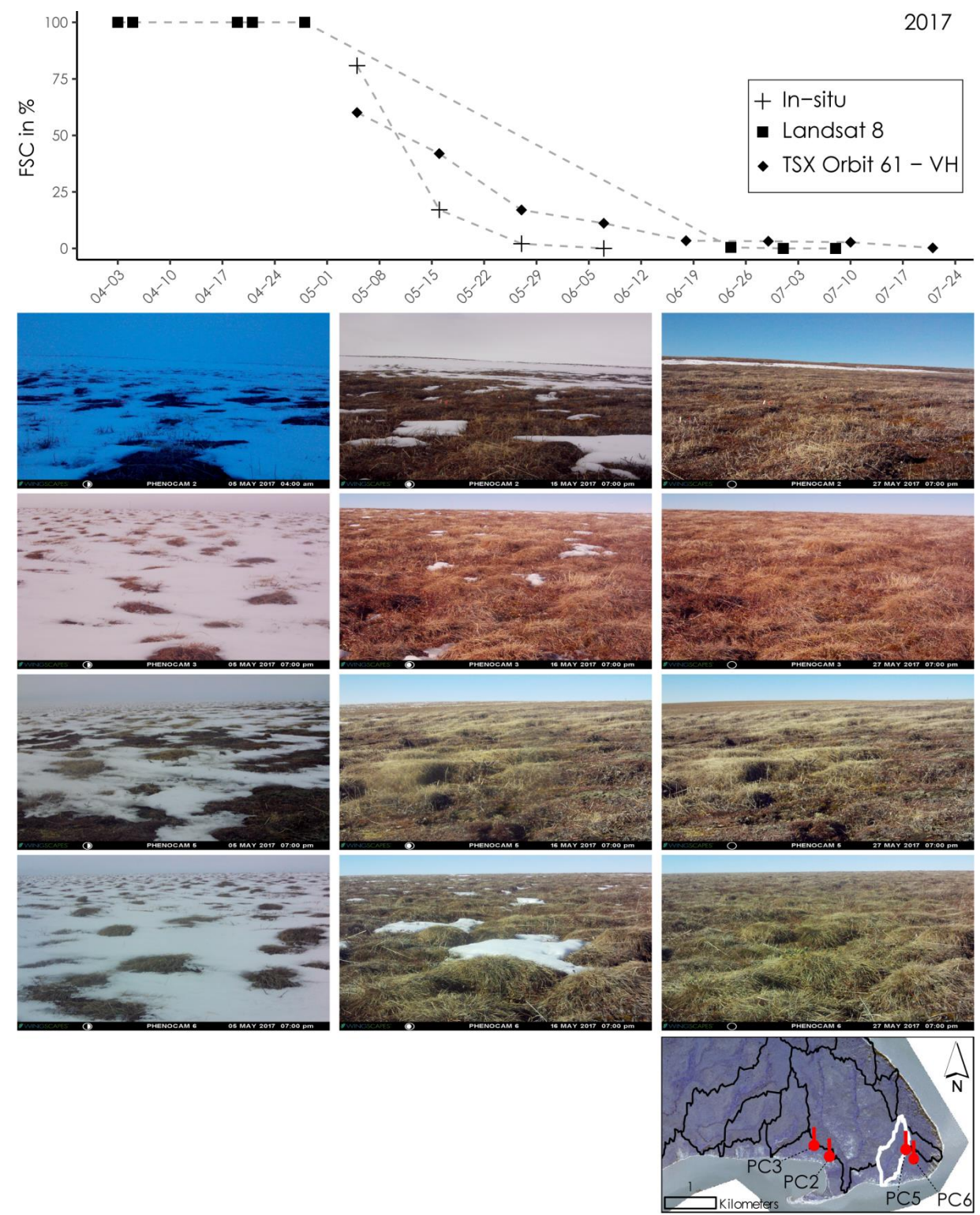

Figure 12. Top graph: Fractional snow cover from time lapse (in situ), Landsat 8 (L8) and TerraSAR-X (TSX) imagery in 2017 in a selected small Arctic catchment (white shape in the map inlet on lower right). Dates on the x-axis show month-day. Time-lapse imagery is from the cameras PC2 (first row) and PC3 (second row), PC5 (third row) and PC6 (fourth row), all representing flat upland tundra locations with low vegetation and tussocks. Dates of the images are the $5^{\text {th }}$ of May (first column), $15 / 16^{\text {th }}$ May (second column) and $27^{\text {th }}$ of May (third column). Camera locations (red dots) and viewing directions (red lines) are shown in the inset map on the lower right. 


\section{Discussion}

\subsection{Spatiotemporal Monitoring of Snowmelt Dynamics Using TSX}

The agreement between TSX and Landsat 8-derived SCE products supports X-Band SAR data as a complementary gap filling data source for detailed spatiotemporal monitoring of snowmelt dynamics at both the landscape and Arctic catchment scale. Overall, the cross polarized VH channel performed best in detecting wet snow and ice layers and also detected late-lying snow patches in protected areas. The better performance in the late season is likely due to ice crystals caused by compaction in the snow pack at this stage of melt. This indicates that the contribution of snow backscatter signals prevails within a pixel late in the season in SAR systems while the optical snow detection capabilities decrease with lower snow albedo and greater vegetation contribution within a pixel later in the season. This is an advantage of a high spatial resolution SAR system over a high resolution optical system for mapping late lying snow patches that are often located in steep topographic areas and create unique abiotic and biotic conditions [79].

Our results suggest that the extraction of wet snow alone is not sufficient to monitor Arctic snowmelt in Qikiqtaruk. The previously documented threshold of $-2 \mathrm{~dB}$ for $\mathrm{VH}$ polarized imagery showed a strong underestimation of SCE when compared to the Landsat SCE [39]. We therefore suggest that the extraction of frozen ice layers is also required to accurately estimate snow cover [80]. A threshold of $1 \mathrm{~dB}$, which includes both wet snow (negative ratio) and ice layers (positive ratio), seems to be a more appropriate threshold in Arctic ecosystems. The threshold of $1 \mathrm{~dB}$ may also result in the inclusion of noise in the SCE maps and a slight overestimation; however, the accuracy is notably better than mapping wet snow alone as the qualitative comparison with the Landsat SCE shows. The TSX product is delivering a wet and frozen snow product. This provides the potential to not only detect snow but also through the use of multiple thresholds, differentiate between the types of snow present.

The TSX data provides a significantly higher temporal resolution than that available with Landsat 8 data alone, revealing the rapid advancement of snowmelt shortly following onset. This provides a better temporal picture of snowmelt dynamics than what can be derived from optical data, which due to cloud cover and subsequent data gaps, generally indicate only the onset and end of snowmelt. A more complete picture of snow cover and snowmelt timing provides an opportunity to better understand the impacts on hydrology, vegetation, active layer and permafrost thermal regimes.

At the catchment scale, two different snowmelt dynamics were observed simultaneously with in situ and TSX data. In a representative area of the Ice Creek catchment with greater topographic variation including steeper slopes and late-lying snow patches, TSX data showed high correspondence to fractional snow cover estimates from time lapse cameras (Figure 11). Both datasets in these steeper topography catchments showed rapid snowmelt followed by a slower snowmelt when only the snow patches remained. When selecting a catchment type with less steep topography characteristic of upland tundra, the TSX FSC time series again showed correspondence to time-lapse imagery with a rapid advancement of snowmelt (Figure 12). Snow patches were also present in the upland tundra and, therefore, prolonged the FSC signal.

On the $9^{\text {th }}$ of June 2016, the time lapse imagery within the lower Ice Creek catchment showed dense fog for 9 hours with no traces of snow on the ground after the fog lifted. The TSX SCE from that date (Figure 13) suggests that new snow cover developed in the upper catchment of the ice creek at higher elevation above the time lapse camera location. This highlights the ability of TSX to potentially capture short-lived snowfall events. Short-term freezing and snowfall events in the spring time can negatively impact early vegetation development and greatly impact hydrological discharge of Arctic catchments and are therefore ecologically important $[16,81]$. 


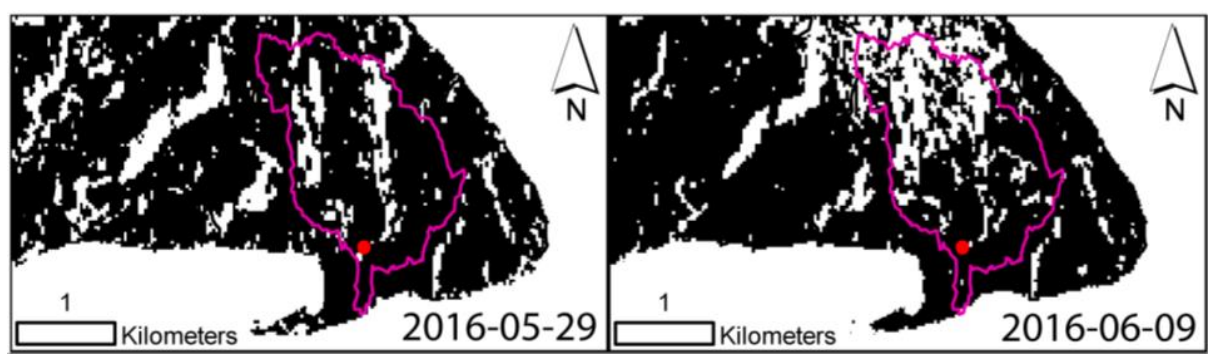

Figure 13. SCE from TerraSAR-X VH from the $29^{\text {th }}$ of April 2016 (left) and from the $9^{\text {th }}$ of May 2016 (right) for the Ice Creek catchment and surroundings. The red dot shows the position of the time lapse camera.

\subsection{Technical Considerations for Using TSX for Wet Snow Detection}

While our method improves the temporal resolution of snowmelt patterns, it faces potential limitations in low Arctic tundra environments. In the later phase of snowmelt, the HH and VV TSX derived FSC were highly variable compared to the Landsat 8-derived FSC. The observed variability indicates that both channels react to other surface features. Nagler et al. [69] also reported lower accuracies of VV compared to the VH channel in C-Band, an effect likely connected to low local incidence angles. In our study, the strong overestimations in VV are also likely influenced by local topography as the areas of false snow detection are predominantly on the flat tundra uplands on the western part of the island. These flat upland areas are likely the first to melt out, highlighting the sensitivity of VV to non-snow surface properties. Limitations in wet snow detection with the VV-polarized X-Band channel has been shown previously with false detection of wet snow in areas of water and (water saturated) bare ground [82]. Additionally, while all polarizations will react to attenuation of the microwave signal in wet snow, the cross polarized $\mathrm{VH}$ probably also reacts to a shift from volume scatter in dry snow to surface scatter on wet snow. This might increase the capability of $\mathrm{VH}$ to distinguish the active melt with liquid water concentrated at the snow surface from liquid water co-existing with the snow pack in vegetation or bare soils.

In addition to bare ground and water, previous research has also demonstrated the sensitivity of TSX (VV/HH polarized) data to the presence of Arctic shrubs and vegetation communities in summer [83], as well as in winter under a dry snow cover [84]. Under both conditions, backscatter is expected to increase with higher shrub density because the fraction of volume scattering increases with taller vegetation. In the case of shrubs that protrude through the snow, backscatter could increase through higher volume scatter and decrease the drop of backscatter between dry snow and wet snow images. As a consequence, the algorithm would detect no snow even though snow is still present between and underneath the shrubs.

Previous research has shown that refreezing of the surface layer can increase the backscatter signal because of the change in dielectric properties of the frozen layer $[43,85]$. This was also confirmed by our analysis of backscatter dynamics. Particularly, the X-band can be sensitive to refreezing snow layers because of its short wavelength and minimal penetration through the frozen layer $[43,69]$. In this context, the observed deviations between the 2015 as well as 2016 data from the 115 and 61 orbits in late April and early May most likely result from the difference in acquisition timing. Orbit 115 acquisitions are taking in the morning local time and 61 in the afternoon (see Table 1). Diurnal variations and resulting freeze thaw cycles are typical for the snowmelt period in the Arctic [12], with typical duration of periods with diurnal freeze thaw cycling in this region being up to 2 weeks [86]. The freezing snow layers can drastically lower the detection of wet SCE when using the wet snow detection threshold of $-2 \mathrm{~dB}$ (see Figure 7: row 2) and, therefore, the derived FSC product if the acquisition time is during the minimum temperatures of the day (Figure 11). The cross polarized channels in C-Band show less angular dependence than the co-polarized channels and, therefore, perform more consistently in deriving snow cover [69]. 
Although there are some limitations for accurate mapping of snow cover with TSX, we were able to show that our $30 \mathrm{~m}$ aggregated TSX SCE product added valuable information to the characterization of 3 years of snowmelt data in Arctic catchments. In combination with optical data from Landsat 8 , a complete picture of snowmelt can be drawn, including short term snow dynamics. The potential of full spatial resolution TSX in combination with an optimized speckle filter for SCE generation would open up more applications for fine scale monitoring of the impact of snow melt dynamics on ecosystem functioning in heterogeneous Arctic tundra environments.

\section{Conclusions}

The results of this study highlight the potential of TerraSAR-X X-Band to improve and complement existing optical based snow cover products by increasing the temporal resolution of snow cover measurements. We identified the VH channel as the best performing polarization channel. When we used common thresholds of -2 and $-2.3 \mathrm{~dB}$ on TSX images, SCE was strongly underestimated when compared to Landsat $8 \mathrm{SCE}$ maps, while a threshold of $1 \mathrm{~dB}$ produced very comparable results to Landsat $8 \mathrm{SCE}$. The VH polarization used with a threshold of $1 \mathrm{~dB}$ also showed an advantage by detecting reduced backscatter due to wet snow as well as increased backscatter due to ice layers. The positive threshold and detection of ice layers resulted in the detection of late lying snow patches that Landsat 8 did not capture due to the lower reflectance of old snow. Differences in the incidence angle did not seem to have a strong effect on the accuracy of the SCE, though local topography and resulting incidence angle likely led to false snow detection in the co-polarized channels. The TSX data provides a significantly higher temporal resolution than that available with Landsat 8 data alone. This provides a much more complete temporal picture of snowmelt dynamics than the optical data which, due to data gaps as a result of cloud cover, generally indicates only the onset and end of snowmelt. Using both in situ time lapse camera data and TSX imagery, we could show that depending on catchment topography, different temporal patterns of snowmelt exist. A studied catchment with a higher tundra upland contribution showed faster snowmelt than a catchment with a higher contribution of incised valleys. Overall, we conclude that a multi-source approach using conventional optical data in combination with high spatiotemporal resolution SAR in X-Band and in situ time lapse camera data is very well suited to study rapid snowmelt in small Arctic catchments.

Supplementary Materials: The following are available online at http:/ / www.mdpi.com/2072-4292/10/7/1155/s1, Figure S1: Figure S1 Comparison of Landsat 8 SCE (left panels) and corresponding TSX SCE derived using a threshold of -2 and $-2.3 \mathrm{~dB}$ on the $\mathrm{HH}$ (center panels) and VV (left panels) polarized channels of orbit 24, respectively with results of the accuracy assessment., Figure S2: Figure S2 Comparison of Landsat 8 SCE (left panels) and corresponding TSX SCE derived using a threshold of -2 and $-2.3 \mathrm{~dB}$ on the $\mathrm{HH}$ (center panels) and VV (left panels) polarized channels of orbit 137 with results of the accuracy assessment., Figure S3: Figure S3 Comparison of Landsat 8 SCE (left panels) and corresponding TSX SCE derived using a threshold of -2 and $-2.3 \mathrm{~dB}$ on the $\mathrm{HH}$ (center panels) and VV (left panels) polarized channels of orbit 152 with results of the accuracy assessment., Figure S4, Comparison of Landsat 8 SCE (left panels) and corresponding TSX SCE derived using a threshold of $1 \mathrm{~dB}$ on the $\mathrm{HH}$ (center panels) and VV (left panels) polarized channels of orbit 24, respectively with results of the accuracy assessment. Figure S5: Figure S5 Comparison of Landsat 8 SCE (left panels) and corresponding TSX SCE derived using a threshold of $1 \mathrm{~dB}$ on the $\mathrm{HH}$ (center panels) and VV (left panels) polarized channels of orbit 137 with results of the accuracy assessment., Figure S6: Figure S3 Comparison of Landsat 8 SCE (left panels) and corresponding TSX SCE derived using a threshold of $1 \mathrm{~dB}$ on the HH (center panels) and VV (left panels) polarized channels of orbit 152 with results of the accuracy assessment., Table S1: List of TSX scenes per relative orbit that were used for the averaged dry snow, Table S2: Fractional snow cover from independent visual estimations of in situ time lapse imagery.

Author Contributions: Conceptualization, S.S., H.L. and B.H.; Data curation, S.S. and A.R.; Formal analysis, S.S.; Investigation, S.S., J.E., A.B. and B.R.; Methodology, S.S., J.E., A.B. and B.R.; Resources, B.H.; Validation, S.S., H.L. and B.H.; Visualization, S.S.; Writing—original draft, S.S.; Writing—review \& editing, H.L., B.H., J.E., A.R., A.B. and B.R.

Funding: The authors want to thank the German Helmholtz Alliance Earth System Dynamics (EDA) for funding of this project and access to the TSX datasets. Samuel Stettner and Hugues Lantuit were additionally supported through HGF COPER, Annett Bartsch through the European Space Agency project DUE GlobPermafrost (Contract Number 4000116196/15/I-NB) and Birgit Heim through the Helmholtz program for Regional Climate Change REKLIM. 
Acknowledgments: The authors thank Isla Myers-Smith and Team Shrub setting up and sharing the data of the phenology time-lapse cameras, funding for this research was provided by NERC through the ShrubTundra (NE/M016323/1) standard grant. We thank George Tanski (AWI Potsdam), Jan Kahl (AWI Potsdam), Samuel McLeod (Herschel Ranger) and Edward McLeod (Herschel Ranger) for setting up the time lapse camera in spring 2016 possible. The authors thank Mike Kubanski from the SARlab in Vancouver. The authors want to thank the Rangers of Herschel Island and the Aurora Research Institute for making the field work in this remote area possible. We thank Nicholas Coops and the IRSS lab at University of British Columbia for providing an excellent working environment during the processing of the optical satellite imagery for this work. We thank the Inuvialuit People for the opportunity to conduct research on their traditional lands.

Conflicts of Interest: The authors declare no conflict of interest.

\section{References}

1. Ling, F.; Zhang, T. Impact of the timing and duration of seasonal snow cover on the active layer and permafrost in the Alaskan Arctic. Permafr. Periglac. Process. 2003, 14, 141-150. [CrossRef]

2. Zhang, T.; Stamnes, K. Impact of climatic factors on the active layer and permafrost at Barrow, Alaska. Permafr. Periglac. Process. 1998, 9, 229-246. [CrossRef]

3. Zhang, T.; Osterkamp, T.E.; Stamnes, K. Influence of the depth hoar layer of the seasonal snow cover on the ground thermal regime. Water Resour. Res. 1996, 32, 2075-2086. [CrossRef]

4. Johansson, M.; Callaghan, T.V.; Bosiö, J.; Åkerman, H.J.; Jackowicz-Korczynski, M.; Christensen, T.R. Rapid responses of permafrost and vegetation to experimentally increased snow cover in sub-arctic Sweden. Environ. Res. Lett. 2013, 8, 035025. [CrossRef]

5. Semenchuk, P.R.; Elberling, B.; Amtorp, C.; Winkler, J.; Rumpf, S.; Michelsen, A.; Cooper, E.J. Deeper snow alters soil nutrient availability and leaf nutrient status in high Arctic tundra. Biogeochemistry 2015, 124, 81-94. [CrossRef]

6. Schimel, J.P.; Bilbrough, C.; Welker, J.A.; Schimel, J.P.; Bilbrough, C.; Welker, J.M. Increased snow depth affects microbial activity and nitrogen mineralization in two Arctic tundra communities. Soil Biol. Biochem. 2004, 36, 217-227. [CrossRef]

7. Krab, E.J.; Roennefarth, J.; Becher, M.; Blume-Werry, G.; Keuper, F.; Klaminder, J.; Kreyling, J.; Makoto, K.; Milbau, A.; Dorrepaal, E. Winter warming effects on tundra shrub performance are species-specific and dependent on spring conditions. J. Ecol. 2018, 106, 599-612. [CrossRef]

8. Ballantyne, C.K. The Hydrologic Significance of Nivation Features in Permafrost Areas. Geogr. Ann. Ser. A Phys. Geogr. 1978, 60, 51-54. [CrossRef]

9. Schimel, J.P.; Kielland, K.; Chapin, F.S. Nutrient Availability and Uptake by Tundra Plants. In Landscape Function and Disturbance in Arctic Tundra; Springer: Berlin/Heidelberg, Germany, 1996; pp. 203-221.

10. Ostendorf, B.; Quinn, P.; Beven, K.; Tenhunen, J.D. Hydrological Controls on Ecosystem Gas Exchange in an Arctic Landscape. In Landscape Function and Disturbance in Arctic Tundra; Springer: Berlin/Heidelberg, Germany, 1996; pp. 369-386.

11. Hobbie, S.E.; Chapin, F.S. Winter regulation of tundra litter carbon and nitrogen dynamics. Biogeochemistry 1996, 35, 327-338. [CrossRef]

12. Bartsch, A.; Kidd, R.A.; Wagner, W.; Bartalis, Z. Temporal and spatial variability of the beginning and end of daily spring freeze/thaw cycles derived from scatterometer data. Remote Sens. Environ. 2007, 106, 360-374. [CrossRef]

13. Brooks, P.D.; Grogan, P.; Templer, P.H.; Groffman, P.; Öquist, M.G.; Schimel, J. Carbon and Nitrogen Cycling in Snow-Covered Environments. Geogr. Compass 2011, 5, 682-699. [CrossRef]

14. Woo, M. Hydrology of a small Canadian High Arctic basin during the snowmelt period. Catena 1976, 3 , 155-168. [CrossRef]

15. Billings, W.D.; Mooney, H.A. The Ecology of Arctic Plants. Biol. Rev. 1968, 43, 481-529. [CrossRef]

16. Hinzman, L.D.; Kane, D.L.; Benson, C.S.; Everett, K.R. Energy Balance and Hydrological Processes in an Arctic Watershed. In Landscape Function and Disturbance in Arctic Tundra; Springer: Berlin/Heidelberg, Germany, 1996; pp. 131-154.

17. Pohl, S.; Marsh, P. Modelling the spatial-temporary variability of spring snowmelt in an arctic catchment. Hydrol. Process. 2006, 20, 1773-1792. [CrossRef] 
18. Billings, W.D.; Bliss, L.C. An alpine snowbank environment and its effects on vegetation, plant development, and productivity. Ecology 1959, 40, 388-397. [CrossRef]

19. Bjorkman, A.D.; Elmendorf, S.C.; Beamish, A.L.; Vellend, M.; Henry, G.H.R. Contrasting effects of warming and increased snowfall on Arctic tundra plant phenology over the past two decades. Glob. Chang. Biol. 2015, 21, 4651-4661. [CrossRef] [PubMed]

20. Brown, R.D.; Robinson, D.A. Northern Hemisphere spring snow cover variability and change over 1922-2010 including an assessment of uncertainty. Cryosphere 2011, 5, 219-229. [CrossRef]

21. Weller, G.; Symon, C.; Arris, L.; Hill, B. Summary and synthesis of the ACIA. In Arctic Climate Impact Assessment; Campbridge University Press: New York, NY, USA, 2005; pp. 990-1020.

22. Clark, M.P.; Hendrikx, J.; Slater, A.G.; Kavetski, D.; Anderson, B.; Cullen, N.J.; Kerr, T.; Örn Hreinsson, E.; Woods, R.A. Representing spatial variability of snow water equivalent in hydrologic and land-surface models: A review. Water Resour. Res. 2011, 47. [CrossRef]

23. Liston, G.E.; Liston, G.E. Representing Subgrid Snow Cover Heterogeneities in Regional and Global Models. J. Clim. 2004, 17, 1381-1397. [CrossRef]

24. Sturm, M.; Holmgren, J.; McFadden, J.P.; Liston, G.E.; Chapin, F.S.; Racine, C.H.; Sturm, M.; Holmgren, J.; McFadden, J.P.; Liston, G.E.; et al. Snow-Shrub Interactions in Arctic Tundra: A Hypothesis with Climatic Implications. J. Clim. 2001, 14, 336-344. [CrossRef]

25. Myers-Smith, I.H.; Forbes, B.C.; Wilmking, M.; Hallinger, M.; Lantz, T.; Blok, D.; Tape, K.D.; Macias-Fauria, M.; Sass-Klaassen, U.; Lévesque, E.; et al. Shrub expansion in tundra ecosystems: Dynamics, impacts and research priorities. Environ. Res. Lett. 2011, 6, 045509. [CrossRef]

26. Strozzi, T.; Wegmuller, U.; Matzler, C. Mapping wet snowcovers with SAR interferometry. Int. J. Remote Sens. 1999, 20, 2395-2403. [CrossRef]

27. Dietz, A.J.; Kuenzer, C.; Gessner, U.; Dech, S.; Juergen, A.; Kuenzer, C.; Gessner, U.; Dech, S.; Dietz, A.J.; Kuenzer, C.; et al. Remote sensing of snow-A review of available methods. Int. J. Remote Sens. 2012, 33, 4094-4134. [CrossRef]

28. Irons, J.R.; Dwyer, J.L.; Barsi, J.A. The next Landsat satellite: The Landsat Data Continuity Mission. Remote Sens. Environ. 2012, 122, 11-21. [CrossRef]

29. Salomonson, V.V.; Appel, I. Estimating fractional snow cover from MODIS using the normalized difference snow index. Remote Sens. Environ. 2004, 89, 351-360. [CrossRef]

30. Stow, D.A.; Hope, A.; McGuire, D.; Verbyla, D.; Gamon, J.; Huemmrich, F.; Houston, S.; Racine, C.; Sturm, M.; Tape, K.; et al. Remote sensing of vegetation and land-cover change in Arctic Tundra Ecosystems. Remote Sens. Environ. 2004, 89, 281-308. [CrossRef]

31. Romanov, P.; Gutman, G.; Csiszar, I.; Romanov, P.; Gutman, G.; Csiszar, I. Automated Monitoring of Snow Cover over North America with Multispectral Satellite Data. J. Appl. Meteorol. 2000, 39, 1866-1880. [CrossRef]

32. Roth, A.; Eineder, M.; Schättler, B. TerraSAR-X: A new persepctive for applications requiring high resolution spaceborne SAR data. 2003. Available online: https://www.ipi.uni-hannover.de/fileadmin/institut/pdf/ roth.pdf (accessed on 21 July 2018).

33. Rott, H.; Heidinger, M.; Nagler, T.; Cline, D.; Yueh, S. Retrieval of snow parameters from Ku-band and $\mathrm{X}$-band radar backscatter measurements. In Proceedings of the IEEE International Geoscience and Remote Sensing Symposium, Cape Town, South Africa, 12-17 July 2009; pp. II-144-II-147.

34. Ulaby, F.T.; Stiles, W.H. The active and passive microwave response to snow parameters: 2. Water equivalent of dry snow. J. Geophys. Res. 1980, 85, 1045. [CrossRef]

35. Mätzler, C.; Wegmüller, U. Dielectric properties of freshwater ice at microwave frequencies. J. Phys. D Appl. Phys. 1987, 20, 1623-1630. [CrossRef]

36. Mätzler, C. Passive microwave signatures of landscapes in winter. Meteorol. Atmos. Phys. 1994, 54, $241-260$. [CrossRef]

37. Leinss, S.; Parrella, G.; Hajnsek, I. Snow height determination by polarimetric phase differences in X-Band SAR Data. IEEE J. Sel. Top. Appl. Earth Obs. Remote Sens. 2014, 7, 3794-3810. [CrossRef]

38. Schellenberger, T.; Ventura, B.; Zebisch, M.; Notarnicola, C. Wet Snow Cover Mapping Algorithm Based on Multitemporal COSMO-SkyMed X-Band SAR Images. IEEE J. Sel. Top. Appl. Earth Obs. Remote Sens. 2012, 5 , 1045-1053. [CrossRef] 
39. Schellenberger, T.; Ventura, B.; Notarnicola, C.; Zebisch, M.; Nagler, T.; Rott, H. Exploitation of Cosmo-Skymed image time series for snow monitoring in alpine regions. In Proceedings of the 2011 IEEE International Geoscience and Remote Sensing Symposium, Vancouver, BC, Canada, 24-29 July 2011; pp. 3641-3644. [CrossRef]

40. Nagler, T.; Rott, H. Retrieval of wet snow by means of multitemporal SAR data. IEEE Trans. Geosci. Remote Sens. 2000, 38, 754-765. [CrossRef]

41. Rott, H.; Nagler, T. Snow and glacier investigations by ERS-1 SAR: First results. In Proceedings of the 1st ERS-1 Symposium: Space at the Service of our Environment, Cannes, France, 4-6 November 1992; pp. 577-582.

42. Nagler, T. Methods and Analysis of Synthetic Aperture Radar Data for ERS-1 and X-SAR for Snow and Glacier Applications. Ph.D. Thesis, University of Innsbruck, Innsbruck, Austria, 1996.

43. Floricioiu, D.; Rott, H. Seasonal and short-term variability of multifrequency, polarimetric radar backscatter of alpine terrain from SIR-C/X-SAR and AIRSAR data. IEEE Trans. Geosci. Remote Sens. 2001, 39, 2634-2648. [CrossRef]

44. Bartsch, A.; Kumpula, T.; Forbes, B.C.; Stammler, F. Detection of snow surface thawing and refreezing in the Eurasian Arctic with QuikSCAT: Implications for reindeer herding. Ecol. Appl. 2010, 20, 2346-2358. [CrossRef] [PubMed]

45. Kimball, J.S.; McDonald, K.C.; Keyser, A.R.; Frolking, S.; Running, S.W. Application of the NASA scatterometer (NSCAT) for determining the daily frozen and nonfrozen landscape of Alaska. Remote Sens. Environ. 2001, 75, 113-126. [CrossRef]

46. Wilson, R.R.; Bartsch, A.; Joly, K.; Reynolds, J.H.; Orlando, A.; Loya, W.M. Frequency, timing, extent, and size of winter thaw-refreeze events in Alaska 2001-2008 detected by remotely sensed microwave backscatter data. Pol. Biol. 2013, 36, 419-426. [CrossRef]

47. Bartsch, A. Monitoring of terrestrial hydrology at high latitudes with scatterometer data. In Geoscience and Remote Sensing New Achievements; Imperatore, P., Riccio, D., Eds.; InTech: Rijeka, Croatia, 2010; p. 64, ISBN 9789537619992.

48. Bartsch, A.; Allard, M.; Biskaborn, B.K.; Burba, G.; Christiansen, H.H.; Duguay, C.R.; Grosse, G.; Günther, F.; Heim, B.; Högström, E.; et al. Permafrost longterm monitoring sites (Arctic and Antarctic). In Requirements for Monitoring of Permafrost in Polar Regions; A Community White Paper Response to WMO Polar Space Task Group (PSTG), Version 4, 2014-10-09; Austrian Polar Res. Institute: Vienna, Austria, 2014.

49. Burn, C.R. Herschel Island Qikiqtaryuk: A Natural and Cultural History; University of Calgary Press: Calgary, Alberta, 2012; pp. 48-53.

50. Solomon, S.M. Spatial and temporal variability of shoreline change in the Beaufort-Mackenzie region, northwest territories, Canada. Geo-Mar. Lett. 2005, 25, 127-137. [CrossRef]

51. De Krom, V. Retrogressive Thaw Slumps and Active Layer Slides on Herschel Island, Yukon. Unpublished Master's Thesis, McGill University, Montréal, QC, Canada, 1990.

52. Rampton, V.N. Quaternary geology of the Yukon Coastal Plain. Geol. Surv. Can. Bull. 1982, 49. [CrossRef]

53. Walker, D.A.; Raynolds, M.K.; Daniëls, F.J.A.; Einarsson, E.; Elvebakk, A.; Gould, W.A.; Katenin, A.E.; Kholod, S.S.; Markon, C.J.; Melnikov, E.S. The circumpolar Arctic vegetation map. J. Veg. Sci. 2005, 16, 267-282. [CrossRef]

54. Bliss, L.C. Arctic ecosystems of North America. In Polar and Alpine Tundra; Elsevier: Amsterdam, Netherlands, 1997; pp. 551-683.

55. Smith, C.A.S.; Kennedy, C.E.; Hargrave, A.E.; McKenna, K.M. Soil and Vegetation of Herschel Island, Yukon territory; Land Resource Research Centre, Agriculture Canada: Ottawa, ON, Canada, 1989.

56. Myers-smith, I.H.; Hik, D.S.; Kennedy, C.; Cooley, D.; Johnstone, J.F.; Kenney, A.J.; Krebs, C.J. Expansion of Canopy-Forming Willows Over the Twentieth Century on Herschel Island, Yukon Territory, Canada. AMBIO A J. Hum. Environ. 2011, 40, 610-623. [CrossRef]

57. Kennedy, C.E.; Smith, C.A.S.; Cooley, D.A. Observations of change in the cover of polargrass, Arctagrostis latifolia, and arctic lupine, Lupinus arcticus. Upl. Tundra Herschel Isl. Yukon Territ. Can. Field-Nat 2001, 115, 323-328.

58. Blasco, S.M.; Fortin, G.; Hill, P.R.; O'Connor, M.J.; Brigham-Grette, J. The late Neogene and Quaternary stratigraphy of the Canadian Beaufort continental shelf. In The Arctic Ocean Region; Geological Society of America: Boulder, CO, USA, 1990; pp. 491-502. 
59. Fritz, M.; Wetterich, S.; Schirrmeister, L.; Meyer, H.; Lantuit, H.; Preusser, F.; Pollard, W.H. Eastern Beringia and beyond: Late Wisconsinan and Holocene landscape dynamics along the Yukon Coastal Plain, Canada. Palaeogeogr. Palaeoclimatol. Palaeoecol. 2012, 319-320, 28-45. [CrossRef]

60. Burn, C.R.; Zhang, Y. Permafrost and climate change at Herschel Island (Qikiqtaruq), Yukon Territory, Canada. J. Geophys. Res. 2009, 114, F02001. [CrossRef]

61. Kokelj, S.V.; Smith, C.A.S.; Burn, C.R. Physical and chemical characteristics of the active layer and permafrost, Herschel Island, western Arctic Coast, Canada. Permafr. Periglac. Process. 2002, 13, 171-185. [CrossRef]

62. Couture, N.J.; Pollard, W.H. A Model for Quantifying Ground-Ice Volume, Yukon Coast, Western Arctic Canada. Permafr. Periglac. Process. 2017, 28, 534-542. [CrossRef]

63. Fritz, M.; Opel, T.; Tanski, G.; Herzschuh, U.; Meyer, H.; Eulenburg, A.; Lantuit, H. Dissolved organic carbon (DOC) in Arctic ground ice. Cryosphere Discuss. 2015, 9, 77-114. [CrossRef]

64. Lantuit, H.; Pollard, W.H.; Couture, N.; Fritz, M.; Schirrmeister, L.; Meyer, H.; Hubberten, H. Modern and Late Holocene Retrogressive Thaw Slump Activity on the Yukon Coastal Plain and Herschel Island, Yukon Territory, Canada. Permafr. Periglac. Process. 2012, 51, 39-51. [CrossRef]

65. Ramage, J.L.; Fortier, D.; Hugelius, G.; Lantuit, H.; Morgenstern, A. Dissecting valleys: Snapshot of carbon and nitrogen distribution in Arctic valleys. Catena 2018, Submitt.

66. Obu, J.; Lantuit, H.; Myers-Smith, I.; Heim, B.; Wolter, J.; Fritz, M. Effect of Terrain Characteristics on Soil Organic Carbon and Total Nitrogen Stocks in Soils of Herschel Island, Western Canadian Arctic. Permafr. Periglac. Process. 2017, 28, 92-107. [CrossRef]

67. Meese, R.J.; Tomich, P.A. Dots on the rocks: A comparison of percent cover estimation methods. J. Exp. Mar. Bio. Ecol. 1992, 165, 59-73. [CrossRef]

68. Nagler, T.; Rott, H. Snow classification algorithm for Envisat ASAR. In Proceedings of the 2004 Envisat \& ERS Symposium, Salzburg, Austria, 6-10 September 2004; Volume 572.

69. Nagler, T.; Rott, H.; Ripper, E.; Bippus, G.; Hetzenecker, M. Advancements for Snowmelt Monitoring by Means of Sentinel-1 SAR. Remote Sens. 2016, 8, 348. [CrossRef]

70. Wendleder, A.; Heilig, A.; Schmitt, A.; Mayer, C. Monitoring of Wet Snow and Accumulations at High Alpine Glaciers Using Radar Technologies. ISPRS Int. Arch. Photogramm. Remote Sens. Spat. Inf. Sci. 2015, 40, 1063-1068. [CrossRef]

71. Venkataraman, G. Snow cover area monitoring using multitemporal TerraSAR-X data. In Proceedings of the 3rd TerraSAR-X Science Team Meeting, Oberpfaffenhofen, Germany, 25-26 November 2008.

72. Lee, J.-S. A simple speckle smoothing algorithm for synthetic aperture radar images. IEEE Trans. Syst. Man. Cybern. 1983, 85-89. [CrossRef]

73. Frost, V.S.; Stiles, J.A.; Shanmugan, K.S.; Holtzman, J.C. A model for radar images and its application to adaptive digital filtering of multiplicative noise. IEEE Trans. Pattern Anal. Mach. Intell. 1982, 157-166. [CrossRef]

74. Krieger, G.; Moreira, A.; Fiedler, H.; Hajnsek, I.; Werner, M.; Younis, M.; Zink, M. TanDEM-X: A satellite formation for high-resolution SAR interferometry. IEEE Trans. Geosci. Remote Sens. 2007, 45, 3317-3341. [CrossRef]

75. Hall, D.K.; Riggs, G.A.; Salomonson, V.V.; DiGirolamo, N.E.; Bayr, K.J. MODIS snow-cover products. Remote Sens. Environ. 2002, 83, 181-194. [CrossRef]

76. Crawford, C.J.; Manson, S.M.; Bauer, M.E.; Hall, D.K. Multitemporal snow cover mapping in mountainous terrain for Landsat climate data record development. Remote Sens. Environ. 2013, 135, 224-233. [CrossRef]

77. Hall, D.K.; Riggs, G.A.; Salomonson, V.V. Development of methods for mapping global snow cover using moderate resolution imaging spectroradiometer data. Remote Sens. Environ. 1995, 54, 127-140. [CrossRef]

78. Foody, G.M. Status of land cover classification accuracy assessment. Remote Sens. Environ. 2002, 80, $185-201$. [CrossRef]

79. Green, K.; Pickering, C.M. The decline of snowpatches in the Snowy Mountains of Australia: Importance of climate warming, variable snow, and wind. Arct. Antarct. Alp. Res. 2009, 41, 212-218. [CrossRef]

80. Bartsch, A.; Kumpula, T.; Forbes, B.C.; Stammler, F. Detection of snow surface thawing and refreezing in the Eurasian Arctic with QuikSCAT: implications for reindeer herding. Ecol. Appl. 2010, 20, 2346-2358. [CrossRef] [PubMed]

81. Inouye, D.W. Effects of climate change on phenology, frost damage, and floral abundance of montane wildflowers. Ecology 2008, 89, 353-362. [CrossRef] [PubMed] 
82. Mora, C.; Jiménez, J.J.; Pina, P.; Catalão, J.; Vieira, G. Evaluation of single-band snow-patch mapping using high-resolution microwave remote sensing: An application in the maritime Antarctic. Cryosphere 2017, 11, 139-155. [CrossRef]

83. Ullmann, T.; Schmitt, A.; Roth, A.; Duffe, J.; Dech, S.; Hubberten, H.-W.; Baumhauer, R. Land Cover Characterization and Classification of Arctic Tundra Environments by means of polarized Synthetic Aperture X- and C-Band Radar (PolSAR) and Landsat 8 Multispectral Imagery-Richards Island, Canada. Remote Sens. 2014, 6, 1-26. [CrossRef]

84. Duguay, Y.; Bernier, M.; Lévesque, E.; Tremblay, B. Potential of C and X Band SAR for Shrub Growth Monitoring in Sub-Arctic Environments. Remote Sens. 2015, 7, 9410-9430. [CrossRef]

85. Reber, B.; Mätzler, C.; Schanda, E. Microwave signatures of snow crusts modelling and measurements. Int. J. Remote Sens. 1987, 8, 1649-1665. [CrossRef]

86. Bartsch, A. Ten Years of SeaWinds on QuikSCAT for Snow Applications. Remote Sens. 2010, 2, $1142-1156$. [CrossRef]

(C) 2018 by the authors. Licensee MDPI, Basel, Switzerland. This article is an open access article distributed under the terms and conditions of the Creative Commons Attribution (CC BY) license (http://creativecommons.org/licenses/by/4.0/). 